\title{
TAX EXPENDITURES: A REASSESSMENT
}

\author{
VICTOR THURONYI*
}

\section{INTRODUCTION}

The concept of "tax expenditures" holds that certain provisions of the tax laws are not really tax provisions, but are actually government spending programs disguised in tax language. ${ }^{1}$ The late Stanley S. Surrey developed the concept nearly twenty years ago. Surrey hoped that if policymakers acknowledged that tax expenditures were spending programs, many would be repealed as an ineffective means of providing a federal subsidy. ${ }^{2}$ In some cases, repealed tax expenditures could be replaced by direct subsidy programs that would furnish government assistance more effectively, ${ }^{3}$ while in other cases, federal assistance could be elimmated entirely. ${ }^{4}$

Although Surrey's concept of tax expenditures has gained official recoguition, it has not been fully integrated into the budget-making process and has largely failed to attain its goals. ${ }^{5}$ A basic theoretical weakness contributes to this failure. Surrey defines tax expenditures as departures from a "norniative income tax," and his norniative tax starts with the Haig-Simons definition of income (or "economic income"): an individual's consumption plus the change in her net worth over a given period. 6 Substantial controversy exists, however, over the meaning of "consumption" in this defintion. Moreover, Surrey's normative tax involves significant departures from economic income in order to accommodate various political and administrative concerns; these compromises have made the idea of a normative mcome tax so inherently subjective that it deprives the tax expenditure concept of its persuasive force.

* Associate Professor of Law, SUNY-Buffalo. M.A., Cambridge; J.D., Harvard, 1980. Special Legal Advisor for Fundamental Tax Reform, U.S. Treasury Department, 1984-1986. The author would like to thank Seymour Fiekowsky for inspiration and Guyora Binder, Cheryl Block, Louis Del Cotto, Daniel Halperin, Fred Konefsky, John Schlegel, and Rob Steinfeld for their comments.

1. See S. Surrey, Pathways to Tax Reform vii (1973).

2. See id. at $179-80$.

3. Id. at 204-07.

4. Id. at 182-203.

5. See infra notes $102-50$ and accompanying text.

6. See S. SURReY \& P. MCDANIEL, TAX EXPENDITURES 186 (1985). Under the Haig-Simons definition, income measures the increase over a given period in an individual's power to consume. Id. 
Congress's half-hearted acceptance of the tax expenditure concept has impeded tax reform and has led to inconsistent legislative treatınent of tax-based and non-tax-based federal subsidies. To foster tax reform and sound budgetary policy, a workable approach to tax expenditures is needed. This Article develops such an alternative approach by formulating a definition of "substitutable tax provisions," a definition not based on the subjective idea of a normative tax. ${ }^{7}$ A substitutable tax provision is a tax law provision whose purposes a non-tax-based federal program can achieve at least as effectively. This definition directs policynakers to two fundamental choices: first, whether to replace certain tax provisions with progranis based outside the tax systeni; and, second, whether to reduce or eliminate the assistance provided by particular tax provisions in light of budgetary priorities.

This alternative approach has several implications. First and most inportantly, the concept of substitutable tax provisions can help policymakers treat tax and spending programs alike for budget-making purposes. ${ }^{8}$ Thus, in contrast to the traditional definition of tax expenditures, the concept of substitutable tax provisions will facilitate tax and budgetary reform. ${ }^{9}$ The alternative definition also suggests that the traditional tax expenditure dichotomy between tax and spending prograins is false. ${ }^{10}$ While some tax law provisions have much in conunon with spending prograins, others are inotivated by both tax and subsidy purposes and cannot be classified as either "tax" or "spending" programs.

The proposed listing of substitutable tax provisions does not imply that the tax expenditure budget, as traditionally defined, should be scrapped. ${ }^{11}$ We should, however, think about the traditional list in a different way. Instead of considering tax expenditures as spending progranis run through the tax systein, we might inore usefully think of them as subsidies. Whether tax expenditures are in the nature of "tax" or "spending" programs is both beside the point and ultimately unanswerable; they are however, subsidies - favored treatment of particular activities. Adnittedly, the assertion that a provision involves a subsidy seems controversial and subjective, because it depends on how the baseline is defined. The subsidy idea may nevertheless prove useful as a way of organizing our thinking about the tax systen and other federal progranis. The budget slould continue to use the traditional tax expenditure list as a means of identifying how the tax system subsidizes various activities.

\footnotetext{
7. See infra notes $176-200$ and accompanying text.

8. See infra notes 220-27 and accompanying text.

9. See infra notes 201-13 and accompanying text.

10. See infra notes $220-58$ and accompanying text.

11. See infra notes 217-19 and accompanying text.
} 
In choosing between tax provisions and non-tax-based programs, though, the concept of substitutable tax provisions is more useful.

\section{The Genesis of the Tax Expenditure ConcePt}

The federal tax laws have long provided favorable treatment for particular transactions and activities. Proponents of tax reform ${ }^{12}$ have decried many of these provisions. They argue that such favorable treatment complicates the tax laws, undermines the progressivity of the system, ${ }^{13}$ provides unduly advantageous treatment to particular taxpayers, and distorts business decisionmaking. ${ }^{14}$ Yet, arguments in favor of reform often fail, and for every argument against a preferential provision, at least one countervailing argument seems to exist. ${ }^{15}$ The current system does not even approach a comprehensive tax on economic income. Because the system exempts particular forms of incoine from tax, one can often argue by analogy for preferential treatment of another item of income. Thus, one can defend a provision that looks to some like an egregious loophole by arguing that it provides treatment equivalent to that of some other item.

The deduction for charitable contributions is a case in point. One can criticize the deduction for not providing a proper measure of income since it allows a deduction for a personal consumption expense. ${ }^{16} \mathrm{~A}$ comprehensive income tax, in contrast, would allow no such deduction. A donor makes contributions to particular organizations as a matter of choice, and the system should treat the contributions the same as the donor's other personal expenses. Opposing arguments can, however, be raised. First, the system should treat a taxpayer who contributes cash earned by her labor the same as a taxpayer who contributes services directly to a charity and is not taxed on the value of such services. For this equal treatment to occur, the cash contribution must be deductible. Second, a taxpayer's expenditures for public purposes should be treated dif-

12. For convenience, I use the term "tax reform" to describe advocacy of amending the tax system to make it more nearly a tax on economic income. Some advocates of tax reform would work toward a different end, such as a tax on consumption.

13. See, e.g., G. Break \& J. Peckman, Federal Tax Reform: The Impossible Dream 11 (1975)

14. See, e.g., 1 OfFice of the Secretary, Dep'T of the Treasury, TAX Reform for Fairness, Simplicity, and Economic Growth: The Treasury Department Report to THE PREsident 1 (1984) [hereinafter TREasury I].

15. "I can't make a damn thing out of this tax problem. I listen to one side and they seem right, and then-God!-I talk to the other side and they seem to be right." Remarks of President Warren G. Harding (1922), reported in J. CONLIN, THE MORROW BOOK OF QUOTATIONS IN AMERICAN HiSTORY 135 (1984).

16. See Kelman, Personal Deductions Revisited: Why They Fit Poorly in an "Ideal" Income Tax and Why They Fit Worse in a Far from Ideal World, 31 STAN. L. REv. 831, 835-58 (1979). 
ferently from her expenditures on goods for private consumption. Finally, and most significantly, any suggestion to repeal or scale back the charitable contribution deduction faces the objection that "we couldn't do that to the charities," which suggests that tax-based governmental support for charities is desirable, or at least politically unassailable. ${ }^{17}$ In sum, the open-endedness of tax-policy analysis and the political power of those who benefit from favorable provisions often lead tax reform to an impasse.

Stanley Surrey developed the tax expenditure concept to resolve such stalemates and advance tax reform. ${ }^{18}$ Surrey wanted to eliminate most preferential tax provisions, but was keenly aware of the difficulty of defeating lobbyists who favored the status quo. In a rhetorically brilliant move, Surrey argued that certain tax provisions should not be considered tax provisions. Rather, these provisions, which Surrey defined as "tax expenditures," were in the nature of government spending programs that happened to be administered through the tax laws. ${ }^{19}$ Under this view, a preferential tax provision operates in two steps: first the taxpayer pays the government the amount called for by the tax laws in the absence of the preferential provision, ${ }^{20}$ and then the government gives the taxpayer a government grant or subsidy. ${ }^{21}$ To save time and simplify administration, the government makes the subsidy payment by reducing the taxpayer's tax liability. ${ }^{22}$ According to Surrey, although the subsidy program is administered through the tax code, it should be treated like a spending program, not like a tax provision..$^{23}$

An example of a tax expenditure is the exclusion for combat pay. ${ }^{24}$ Suppose that a member of the armed forces who is in the $28 \%$ tax bracket receives $\$ 10,000$ in combat pay, none of which is taxed. Under a tax expenditure analysis, this arrangement is equivalent to increasing the soldier's pay to $\$ 13,889$ in order to compensate him for the special

17. For example, in the Tax Reform Act of 1986 (1986 TRA), Pub. L. No. 99-514, 100 Stat. 2085 (codified in scattered sections of I.R.C.), Congress deleted the proposed "floor" on the deduction for charitable contributions in an effort to encourage private giving. See J. BIRNBAUM \& A. MURRAY, SHOWDOWN AT GUCCl GulCH 90 (1987).

18. See S. SURREY, supra note 1, at vii-viii. Surrey can justly be called the father of modern tax policy. A tax lawyer and professor, he served as the influential Assistant Secretary of Treasury for Tax Policy from 1961 to 1969 , and subsequently taught at Harvard Law School. Griswold, $A$ True Public Servant, 98 HARv. L. Rev. 329, 330 (1984).

19. S. SURREY, supra note 1 , at 6 .

20. Id. at 6-7.

21. Id. at 7.

22. See id. at 131-33 (explaining this administrative efficiency argument, but denying its validity).

23. See S. SURREY \& P. MCDANiel, supra note 6, at 3, 6, 25-26.

24. I.R.C. $\S 112$ (1982). 
hazards of combat duty. Both methods of compensation would leave the soldier with $\$ 10,000$ after tax. The tax provision therefore generates a disguised increase in pay for certam military personnel-a government spending program effectuated through the tax laws.

Recharacterizing certaim tax provisions as spending programs in disguise shifts the focus of debate. Instead of arguing whether tax-policy considerations justify a provision, the tax and budget policymakers analyze the provision by comparing it with existing and potential spending programs. This change of focus has major advantages for those seeking repeal of tax expenditures. If analyzed as spending programs, tax expenditures often look absurd.

In contrast to most government subsidy programs, which primarily benefit the needy, tax expenditures often provide an "upside-down" subsidy: benefits from tax expenditures tend to mcrease along with the recipient's wealth. An upside-down subsidy occurs because a tax expenditure benefits only those persons with enough income to pay tax; moreover, if the tax expenditure is structured as a deduction or exclusion, the value of the benefit increases with the recipient's marginal tax rate, and hence with her taxable income. For example, the exclusion of combat pay is more beneficial to taxpayers in higher marginal tax brackets. ${ }^{25}$ The deduction for home mortgage interest provides another example. This deduction amounts to a subsidy for homeownership that excludes the poor, but gives wealthier taxpayers ever larger subsidies depending on their income and the value of their home. ${ }^{26}$ Congress would never have enacted a direct subsidy program structured like this. If the tax expenditure constitutes such a subsidy program, it too must be unacceptable as a matter of policy. ${ }^{27}$

Surrey lampooned the deduction for charitable contributions in a similar manner, asking how Congress might react if the Department of Health, Education and Welfare ${ }^{28}$ proposed to establish a Division of Charitable and Educational Assistance that would distribute its funds as follows:

25. This is the case because the amount of tax benefit that an exclusion provides to a taxpayer equals the amount excluded multiplied by the taxpayer's marginal tax rate. See M. CHIRELSTEIN, FEDERAL InCOME TAXation 345 (5th ed. 1988).

26. See id. $\{7.01$, at 146 . The poor receive no subsidy because only taxpayers who itemize their deductions can deduct home mortgage interest. See I.R.C. § 63(e)(1) (Supp. IV 1986). Poor people do not usually itemize, because the section 63 standard deduction (for use in lieu of itemized deductions) generally exceeds the aggregate of itemized deductions available to them. The subsidy's value also tends to increase with income because persons with higher income are generally in higher

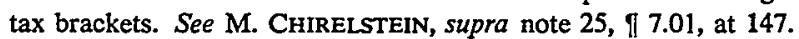

27. See S. SURREY, supra note 1, at 234-46.

28. The Department of Health, Education, and Welfare is now the Department of Education and the Department of Health and Human Services. 
-Suppose a person calls and says: "I am too poor to pay an income tax but I am contributing $\$ 20$ to my favorite charity. Will the Government also help it?" The answer here will be: "We appreciate your sacrifice but we cannot use our funds in this situation."

-Suppose a person calls and says: "I am quite well-off and want to send a check for $\$ 3,000$ to one of my favorite charities ...." The answer here will be: "We are delighted to be of assistance and are at once sending a Government check for $\$ 7,000$ to that charity."

- Suppose a person calls and says: "I am really very wealthy with a considerable fortune in various stocks that originally cost me or my family very little. In fact, I will be selling about $\$ 2$ million of stock .... I I think that a particular charitable institution deserves support and while I have decided not to contribute anything myself, I am calling to inquire whether the Governinent will contribute to it." The answer here will be: "We . . . will be delighted to contribute $\$ 2$ million .... And, in appreciation of your suggesting this to us, we are sending you a check for $\$ 100,000 \ldots . " 29$

Surrey's obvious point is that no such program would ever be proposed, let alone enacted. Yet, if the charitable contribution deduction in fact implements such a program, as tax expenditure analysis asserts, then it too becomes indefensible.

The tax law in force when Surrey wrote certainly had the same effect as the spending program that Surrey described. A poor person could take no deduction for charitable contributions. ${ }^{30} \mathrm{~A}$ person in the $70 \%$ bracket (the highest bracket in the 1970s) who made a $\$ 10,000$ cash contribution could deduct $\$ 10,000$, which would reduce that person's tax liability by $\$ 7,000.31$ Thus, after taxes, the $\$ 10,000$ contribution would cost the contributor only $\$ 3,000$, and the government would in effect make a $\$ 7,000$ matching grant. In Surrey's third situation, a 70\%bracket taxpayer selling stock for a gain of $\$ 2$ million would pay tax on income of $\$ 1$ million (since the $\$ 2$ million gam would be reduced by a deduction for $50 \%$ of long-term capital gains). ${ }^{32}$ The tax liability from the sale would therefore be $\$ 700,000$, with after-tax proceeds of $\$ 1,300,000$. If the taxpayer donated the stock to charity instead, the charitable contribution deduction would save him $\$ 1,400,000$ in tax

29. S. SURREY, supra note 1 , at 228-29.

30. This proposition assumes that a poor person would not have had sufficient itemized deductions to make itemizing worthwhile. See supra note 26.

31. See Tax Reform Act of 1969 (1969 TRA), Pub. L. No. 91-172, sec. 803, § 1, 83 Stat. 487, 678-82 (current version at I.R.C. $\$ 1)(70 \%$ income tax rate on taxable income over $\$ 200,000)$; id. $\S 201(\mathrm{a})(1)(B), 83$ Stat. at 549, 551 (current version at I.R.C. $\$ 170(\mathrm{a})(1)$, (b) (1982)) (allowing deduction for cash charitable contributions not exceeding 50\% of taxpayer's adjusted gross income).

32. See Internal Revenue Act of 1954, Pub. L. No. 83-591, $\S 1202$, 68A Stat. 3, 320, repealed by 1986 TRA, Pub. L. No. 99-514, § 301(a), 100 Stat. 2085, 2216. 
(70\% of $\$ 2$ million). ${ }^{33}$ Thus, the taxpayer would be $\$ 100,000$ better off if he donated stock to charity instead of selling it.

Tax expenditures typically have other drawbacks as well. They complicate the tax laws by straining the tax system's administrative resources; ${ }^{34}$ they generally involve unlimited or uncertain costs; ${ }^{35}$ they evade periodic budgetary review; ${ }^{36}$ and they are administered by the Internal Revenue Service (IRS), an agency unfamiliar with the substantive problems addressed by subsidies and unable to coordinate tax expenditures witl subsidy programs administered by otler agencies. The various subsidies that the tax code provides to dairy farmers illustrate this last objection. The dairy farmer subsidies include accelerated depreciation deductions on livestock and equipment and the acceptance of "cash accounting," both of which defer tax liability with no interest. ${ }^{37}$ While these tax provisions subsidize production and encourage herd expansion, the Department of Agriculture, on the other hand, pays dairy farmers to curtail production and slaugliter their herds. ${ }^{38}$ Such inconsistency in policy would be much less likely if the Department of Agriculture, ratlier than the IRS, provided all subsidies to farmers. If the same congressional committee reviewed and the same agency administered all subsidies in a particular substantive area, at least the subsidies would not simultaneously encourage and discourage the same activity. The result would be consistent and more efficient subsidies.

When compared witl direct spending alternatives, tax expenditures are often inefficient: the subsidies they provide cost the federal government more than direct spending programs would. The tax exclusion for interest on state and local government bonds provides a quintessential example. ${ }^{39}$ The exclusion subsidizes the local government issuer with a

33. See 1969 TRA, Pub. L. No. $91-172$, sec. 803 , $\$ 1,83$ Stat. at $678-82$ (current version at I.R.C. $\$ 1$ (Supp. IV 1986)); id. § 201(a)(1)(B), 83 Stat. at 549, 551-52, 555-56 (current version at I.R.C. $\S 170(\mathrm{a})(1),(\mathrm{b})(1)(\mathrm{B})-(\mathrm{D})$, (e) (1982)).

34. See S. SuRrey \& P. MCDANIEL, supra note 6, at 105-06.

35. The cost of tax expenditures depends on the extent to which taxpayers use them, which cannot be known with certainty in advance. See id. at 102-03, 105.

36. See S. SURREY, supra note 1, at 143-44.

37. Accelerated depreciation deductions, see I.R.C. $\$ 168$ (Supp. IV 1986), reduce taxable income in the beginning of an asset's life, and increase that income by a corresponding amount later in the asset's life. See generally M. CHIRELSTEIN, supra note 25, ๆ 6.08 (discussing economic effect of accelerated depreciation). Assuming a constant tax rate, this has the same effect as if the government lent an amount to the asset owner without charging interest, requiring repayment later in the asset's life. Similarly, cash accounting, see Treas. Reg. $\$ 1.162-12$ (a) (1988), allows farmers to deduct the cost of inputs (such as feed, seed, and fertilizer) when purchased, and to delay reporting income until receipt of the cash proceeds of crop sales. This, too, has the effect of artificially deferring tax liability.

38. 7 U.S.C.A. $\$ 144$ (d) (West 1988).

39. I.R.C. $\S 103$ (Supp. IV 1986); see S. SuRREY, supra note 1, at 210-11. 
reduction in the issuer's borrowing costs. ${ }^{40}$ When holders of tax-exempt bonds are in various tax brackets, as has historically been the case,,$^{41}$ the rate of interest on those bonds cannot fall below the after-tax rate that the lowest-bracket holder of such bonds could obtain on a taxable bond. ${ }^{42}$ Thus, for tax-exempt bonds marketed to investors in the $28 \%$ bracket, the rate of interest must be at least $72 \%$ of the rate on comparable taxable bonds. With the tax-exempt bond interest at this rate, a $28 \%$ bracket holder of a tax-exempt bond would enjoy no special benefit, since her after-tax return would equal the return obtainable on a taxable investment. However, a corporate investor in the $34 \%$ bracket would receive a higher yield on the tax-exempt bond than the after-tax yield on a taxable bond ( $72 \%$ of the taxable bond's yield, versus $66 \%) .{ }^{43}$ The revenue lost by the federal government, in the amount of this benefit to upper-bracket investors, does not benefit the bond issuer. Therefore, direct subsidies to issuers would reduce state and local borrowing costs at less: federal cost than the existing tax provision.

Another important consequence of treating tax expenditures as spending programs is that spending cuts would include cuts in tax expenditure provisions whenever spending retrenchment occurs. If tax expenditures are really spending programs, then whenever Congress contemplates budget reductions, it should subject tax expenditures to the same scrutiny as direct spending programs. By contrast, if Congress treats tax expenditures as "tax" provisions, then it need not address them in cutting expenditures. ${ }^{44}$

Surrey's argument, despite its logical appeal, has enjoyed only minimal success. The following parts of this Article discuss theoretical attacks on the tax expenditure concept ${ }^{45}$ and the concept's limited effect on tax legislation. ${ }^{46}$ The Article then considers whether a reformulation of Surrey's concept could better accomplish his purpose of facilitating the repeal of tax subsidies or the enactment of non-tax-based substitutes if appropriate.

40. See S. Surrey, supra note 1, at 211; D. OTt \& A. Meltzer, Federal TaX Treatment of STATE AND Local SEcurities 114 (1963).

41. For example, when the top marginal income tax rate was $70 \%$, the average marginal tax rate of bondholders was estimated at about $42 \%$. See Miscellaneous Tax Bills: Hearing before the Subcomm. on Taxation and Debt Management Generally of the Comm. on Finance, 96th Cong., 1st Sess, 290 (1979) (statement of Donald C. Lubick, Assistant Secretary of the Treasury).

42. See generally M. CHIRELSTEIN, supra note 25, at 345-51 (discussing economics of state and municipal bonds).

43. See id.

44. S. SuRREY, supra note 1 , at 1-3.

45. See infra notes 77-101 and accompanying text.

46. See infra notes $\mathbf{1 0 2 - 5 0}$ and accompanying text. 


\section{The Problem of Definition}

The central problem with the tax expenditure concept lies in identifying the Internal Revenue Code provisions that contain tax expenditures-spending programs in disguise. In some cases, a tax provision is quite obviously a disguised spending program. For example, under the recently terminated credit for residential energy conservation expenditures, ${ }^{47}$ a homeowner or renter could take a tax credit for $15 \%$ of her expenditures on caulking, insulation, and the like. The provision's only connection with the income tax was its requirement that homeowners or renters claim the credit on their income tax returns, rather than on a mail-in rebate form or other similar device. As the circumstances of the credit's enactment reflect, the credit is simply a government subsidy program for home energy conservation. ${ }^{48}$ Congress could have fulfilled this subsidy purpose just as well with a non-tax-based subsidy program.

While it takes no leap of the imagination to identify the energy conservation credit as a disguised spending program, the tax code contains many other provisions with less transparent subsidy purposes. The purposes behind many long-standing tax provisions are obscure, and often lack coherent and reliable support in legislative history. ${ }^{49}$ These provisions often reflect an inconsistent response to competing policies, making it especially difficult to detect spending programs in disguise. Nor is technical structure a reliable sign of a tax expenditure. An expenditure might take the form of an exclusion from income, ${ }^{50}$ a deduction, ${ }^{51}$ a credit, ${ }^{52}$ a rule deferring recognition of an item of income, ${ }^{53}$ or an accelerated de-

47. I.R.C. $§ 23$ (Supp. IV 1986). The credit ended on December 31, 1985, under section 23's sunset provision. Id. $\$ 23(\mathrm{f})$.

48. The residential energy credit was enacted as section 101 of the Energy Tax Act of 1978, Pub. L. No. 95-618, 92 Stat. 3174, 3175 (codified as amended in scattered sections of I.R.C.). The applicable committee report stated that Congress intended the credit "to provide homeowners and tenants with an incentive to conserve energy by immediate installations of insulatiou and other energy-conserving components." H.R. REP. No. 496, 95th Cong., 1st Sess., pt. 3, at 35, reprinted in 1978 U.S. CODE CONG. \& ADMIN. NEWs 8303, 8330. Unlike reports accompanying other tax bills, this committee report included an estimate of the amount by which the credit would reduce oil and natural gas consumption. See id. at 40, reprinted in 1978 U.S. CoDE CONG. \& ADMIN. NEws at 8335. The report did not, however, discuss why the subsidy was being provided through the tax system rather than by a direct spending program. See id. at 35, reprinted in 1978 U.S. CODE CONG. \& ADMIN. NEws at 8330.

49. E.g., Revenue Act of 1918, ch. 18, $\S 213($ b)(6), 40 Stat. 1057, 1066 (excluding damages received for personal injuries from definition of income); H.R. REP. No. 767, 65th Cong., 2d Sess. 910 (1918) (expressing doubt whether damages for personal injuries included iu calculation of gross income prior to enactment of $1918 \mathrm{Act})$.

50. E.g., I.R.C. § 103(a) (Supp. IV 1986) (exclusion of interest from state and local bonds).

51. E.g., id. §163(a), (h)(3) (West 1988) (deduction for home mortgage interest).

52. E.g., id. $\S \S 38(\mathrm{~b})(2), 51$ (Supp. IV 1986) (credit to businesses for portion of wages paid to section 51(d) targeted employees).

53. E.g., id. $\S 1034$ (1982) (deferral of capital gains on home sales). 
duction. ${ }^{54}$ Not all exclusions, deductions, or credits have been classified as tax expenditures, nor should they be. 55

Surrey defined tax expenditures as provisions giving "special" treatment to particular transactions or activities. ${ }^{56}$ The Budget Act formalized this approach by defining tax expenditures as "revenue losses attributable to provisions of the Federal tax laws which allow a special exclusion, exemption, or deduction from gross income or which provide a special credit, a preferential rate of tax, or a deferral of tax liability."57 Of course, the key word in this definition is "special," but the Budget Act does not define it, nor is its meaning immediately obvious in the context of tax law, given the current law's disparate treatment of various forms of income.

According to Surrey, a tax provision is special if it departs from a normative tax, ${ }^{58}$ i.e., a tax structure that is "generally accepted" by professional tax analysts. ${ }^{59}$ As the Surrey Treasury put it, a tax expenditure is a provision that deviates "from widely accepted definitions of income and standards of business accounting and from the generally accepted structure of an income tax."60

In formulating the normative income tax, Surrey began with the Haig-Simons definition of income: the taxpayer's consumption plus the increase in her net worth during each tax year. ${ }^{61}$ Surrey used this definition as the framework for the normative tax because of its "accept[ance]

54. E.g., id. §174 (Supp. IV 1986) (treatment of research and development expenditures as current expense).

55. For example, the business expense deduction and the foreign tax credit have never been classified as tax expenditures, and properly not. The foreign tax credit simply recognizes the primary taxing jurisdiction of the country in which income was earned. See id. $\$ 901$ (Supp. IV 1986). The total United States and foreign tax paid on foreign-source income is not reduced below the tax that would be due if the income were earned in the U.S. However, rules permitting deferred recognition of the income of foreign subsidiaries, which flow from the fact that foreign corporations are generally not subject to U.S. tax, see id. § 11(d), constitute a tax preference that the foreign tax credit exacerbates. The problem here lies with the deferral rules, not with the credit itself. The business expense deduction is not a preferential provision because those expenses reduce net income and constitute no personal consumption.

56. S. SURREY, supra note 1 , at vii

57. 2 U.S.C. § 622(3) (1982).

58. S. SURREY \& P. MCDANIEL, supra note 6, at 186.

59. Id. at 188 .

60. Id. at 184 (quoting Department of the TREasury, ANNUAl Report of the SeCRE-

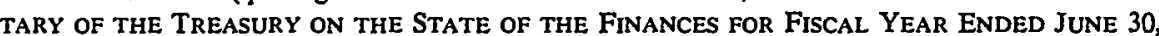
1968 , at $326(1969))$.

61. See id. at 186. Simons established this definition in H. Simons, Personal InCome TAXATION 50 (1938) ("Personal income may te defined as the algebraic sum of (1) the market value of rights exercised in consumption and (2) the change in the value of the store of property rights between the beginning and end of the period in question."). Simons's definition was a more explicit statement of Haig's earlier definition of income as "the money value of the net accretion to one's economic power between two points of time." R.M. HAIG, THE FEDERAL INCOME TAX 7 (1921). 
by most economists in the United States and elsewhere."62 Yet, this definition, without any modifications, would have been problematic. In particular, "consumption" is not self-defiming. It is unclear, for example, whether gifts, charitable contributions, inedical expenses, and personal items lost in casualties are consumption. Business expenses that confer personal enjoyment (such as meals or office decorations) likewise test the limits of the category. ${ }^{63}$ The Haig-Simons defimition is also ambiguous or silent regarding some basic structural features of the tax system, including tax rates and the definition of the taxable unit. For example, while the definition can apply mechanically to both corporations and shareholders, and therefore is arguably consistent with separate corporate and shareholder taxes, some would argue that the concept calls for an integration of those taxes. ${ }^{64}$ Finally, the Haig-Simons definition of income could not realistically provide a foundation for the mcome tax, since it would involve a radical departure from the current systein as well as considerable administrative difficulties. For example, the definition would require annual appraisal of a taxpayer's assets as well as inclusion in the tax base of imputed income on owner-occupied housing and other consuiner durables.

Surrey had no desire to entangle his tax expenditure concept in disputes over the interpretation of Haig-Simons income. ${ }^{65}$ Moreover, he intended the list of tax expenditures to serve at least in part as a reahstic "hit list" for reform. ${ }^{66}$ Identifying all departures from the Haig-Simons definition as tax expenditures would have been overbroad and ineffective, ${ }^{67}$ implicitly advocating reforms that would be administratively infeasible or politically untenable. ${ }^{68}$

For these reasons, Surrey adopted a normative income tax that refined the Haig-Simons definition: he combined "the generally accepted structure of an income tax" 69 and "widely accepted definitions of in-

See H. Simons, supra, at 61-62; see also W. ANDrews, BAsic FEderal Income TAXation 360 (3d ed. 1985) ("Simons' definition is to be taken as a refinement of Haig's, not a new departure.").

62. S. SURREY \& P. MCDANIEL, supra note 6 , at 186.

63. See H. Simons, supra note 61 , at 53-54.

64. See, e.g., Gabinet \& Coffey, The Implications of the Economic Concept of Income for Corporation-Shareholder Income Tax Systems, 27 CASE W. RES. L. REv. 895, 912-17 (1977); see also Musgrave, Pathway to Tax Reform, 98 HaRv. L. Rev. 335, 336 (1984).

65. See S. SURREY \& P. MCDANIEL, supra note 6 , at 187-88.

66. See id.

67. Surrey generally avoided categorical statements that all tax expenditure provisions should be stricken from the tax laws. But in his 1973 book, Pathways to Tax Reform, Surrey could think of only one provision-the investment credit-that he would recommend retaining as a tax expenditure. See S. SURREY, supra note 1, at 206-07.

68. For an example, the Haig-Simons definition of income would call for the taxation of imputed income from home ownership. S. SURREY \& P. MCDANIEL, supra note 6, at 197.

69. Id. at 188 (quoting DEPARTMENT OF THE TREASURY, supra note 60 , at 327 ). 
come,"70 with the proper accounting methods determined according to "widely accepted ... standards of business accounting."71 Surrey's normative tax tempered the Haig-Simons definition by taking account of the historical treatment of various items under the modern U.S. income tax, as well as the consensus of economists and other tax analysts about a politically and administratively realistic tax base. Surrey's normative tax reflected his vision of what the U.S. income tax should look like, given the constraints of politics. By incorporating "generally accepted" concepts, though, Surrey endeavored to shield this subjective vision behind the authority of a consensus of experts. ${ }^{72}$

Disagreement about what the "generally accepted" tax structure is presents an obvious problem with Surrey's approach. Surrey argued, for instance, that since U.S. tax policy has accepted the concept of separate taxation of corporations and shareholders, the normative tax should also assume such separate taxation. ${ }^{73}$ Yet, arguably an integrated taxation of corporations and shareholders should be the norm, since only an integrated system would evenhandedly tax all capital income.

Moreover, untike the Haig-Simons definition, Surrey's normative income tax involves substantial internal inconsistency, caused in part by his need to reconcile competing principles and develop a politically realistic norm. These factors magnify the role of individual judgment in Surrey's normative income tax. ${ }^{74}$ In order to avoid this subjectivity, Surrey relied on his own authority and on the consensus of the experts responsible for developing the tax expenditure list in Congress and the executive branch. ${ }^{75} \mathrm{He}$ even viewed the ambiguity of the tax expenditure concept as beneficial because it would enable the concept to adapt as understanding of the tax system grew. ${ }^{76}$

Despite a consensus among government officials, which led the Office of Management and Budget (OMB) and Congress to promulgate al-

70. Id. (quoting DePARTMENT OF THE TREASURY, supra note 60, at 327).

71. Id. at 189.

72. It is not clear, however, why the consensus of experts should receive such weight. A normative tax ultimately involves value judgments, but the judgments of public finance economists or tax lawyers are not necessarily superior to those of nonspecialists.

73. Id. at 215 (stating that tax theory considers neither full integration nor separation as normative).

74. See infra notes $85-86$ and accompanying text.

75. These experts were typically either former students, subordinates, or associates of Surrey, and were generally interested in fostering a public consensus despite possible private disagreements. Cf. Andrews, $A$ Source of Inspiration, 98 HARV. L. REv. 332, 334 (1984) (paying tribute to Surrey's influence on younger policy officials in the Treasury, who continued to develop and implement his ideas after he returned to academia).

76. See, e.g., S. SURREY \& P. MCDANIEL, supra note 6, at 198 (suggesting that as understanding of the tax system grows, "the initial Treasury decision to exclude [unrealized gains] from the tax expenditure list should be reexamined"). 
most identical tax expenditure lists (at least until 1982), ${ }^{77}$ the academic literature has presented considerable dispute over the makeup of the tax expenditure budget, and on the meaningfulness of the tax expenditure concept in general. A brief review of this hterature, focusing on articles by Professors Andrews, Bittker, and Blum, will illustrate the advantages of a tax expenditure definition that does not rely on a normative income tax.

Professor Andrews agrees with the approach of defining tax expenditures as departures from an ideal income tax, ${ }^{78}$ but argues that "the ideal for this purpose must be carefully shaped and refined to reflect the intrinsic objectives of the tax." 79 To him, a provision that departs from HaigSimons but constitutes "a refinement in our notion of an ideal personal income tax" does not constitute a tax expenditure..$^{80}$ Andrews concludes that deductions for charitable contributions and for medical expenses comport with an ideal income tax by contributing to the accurate measurement of personal consumption, and therefore should not be treated as tax expenditures. ${ }^{81} \mathrm{He}$ suggests, moreover, that other personal deductions (for interest and state and local taxes, for example) might be appropriate elements of an ideal income tax. ${ }^{82}$

Professor Bittker remains more pessimistic about the tax expenditure concept's validity. He argues that systematically compiling a list of tax expenditures requires "not an ad hoc list of tax provisions, but a generally acceptable model, or set of principles, enabling us to decide with reasonable assurance which income tax provisions are departures from the model, whose costs are to be reported as 'tax expenditures [in the budget]." "83 For Bittker, the concept of tax expenditures "is feasible only to the extent that we can agree on a conceptual model." 84 But because of ambiguities in the Haig-c.imons definition of income and its failure to address structural tax issues,

77. Compare OMB, Budget of the United States Government, Fiscal Year 1981SpeCial ANAlyses 230-34 (1980) with Senate Comm. ON the Budget, 97TH Cong., 2D Sess., Tax Expenditures: Relationships to Spending Programs and Background Material on Individual Provisions (Comm. Print 1982). See also infra notes 167-70 and accompanying text.

78. Andrews, Personal Deductions in an Ideal Income Tax, 86 HARv. L. REv. 309, 312 (1972).

79. Id.

80. Id.

81. Id. at $335-37$ (medical expenses); id. at $365-67$ (charitable contributions).

82. Id. at 376 (since payments for interest and for state and local taxes do not constitute personal consumption, earnings used for these should not be included in tax system's definition of income).

83. Bittker, Accounting for Federal "Tax Subsidies" in the National Budget, 22 NAT'L TAX J. 244,247 (1969).

84. Id. at 260 . 
every man can create his own set of "tax expenditures," but it will be no more than his collection of disparities between the income tax law as it is, and as he thinks it ought to be.... I do not know how we can select one of them for inclusion in the National Budget. ${ }^{85}$

Thus, Professor Bittker concludes that the tax expenditure concept is inherently ambiguous, even with the Haig-Simons definition as a benchmark. This ambiguity is especially extreme if the baseline income tax explicitly departs from Haig-Simons in ways not mandated by any general principle. Such a baseline necessarily reflects ad hoc value judgments, since a value-free "correct tax structure" is impossible. ${ }^{86}$

Professor Blum maintains that some tax expenditures can be identified without reference to a normative tax. He suggests dividing Surrey's tax expenditures into two categories. "One group consists of the preferential provisions that everyone agrees are incentive measures that cannot be defended on grounds of tax equity, tax administration, or other tax considerations. These items . . . are clearly designed to accomplish a social or economic goal that is not related to the tax system."87 An item in this category "is correctly viewed as a tax expenditure . . not because of any normative judgment about the proper contours of the income tax, but because it is universally conceded to be an incentive measure that has no tax justification."88 Items falling outside this category, according to Blum, qualify as tax expenditures "only in terms of a normative judgment."89

As the residential energy credit demonstrates, 90 there are some tax provisions that no one would seek to justify with tax-policy considerations. But most tax expenditures fall in the gray area: they fulfill a subsidy function, but show some merit on tax-related grounds as well. Indeed, the very example Blum uses, ${ }^{91}$ the fast write-off for pollution

85. Id.

86. Bittker, The Tax Expenditure Budget-A Reply to Professors Surrey and Hellmuth, 22 NAT'L TAX J. 538, 542 (1969). Professor Kahn also argues that the formulation of the normative income tax for the purpose of identifying tax expenditures involves "value judgments," and that the Treasury Department's claim to have "discovered the true and correct 'model" of net income" is unsupported. Kahn, Accelerated Depreciation-Tax Expenditure or Proper Allowance for Measuring Nct Income?, 78 Mich. L. Rev. 1, 6 (1979). Kahn acknowledges that "[t]o the extent that the tax expenditure concept seeks to regularize such reexaminations [of the tax laws], it has a laudatory [sic] goal," but that in light of serious questions about the proper classification of numerous items as tax expenditures, "[t]he inclusion of an item in the [Tax Expenditure] Budget tends to squelch such inquiries." Id. at 54-55.

87. Blum, Book Review, 1 J. CoRp. TAX'N 486, 488 (1975) (reviewing S. SURREY, supra note 1).

88. Id.

89. Id.

90. See supra notes $47-48$ and accompanying text.

91. See Blum, supra note 87 , at 488 . 
control equipment,, 92 can be defended on tax-policy grounds. One could argue that the imposition of environmental controls has saddled polluters with a one-time economic loss that the tax code has not taken into account. Allowing an accelerated deduction for the costs of comphance properly measures net incoine. Moreover, if the tax system did not allow rapid deductions for pollution control equipment, polluters might move their operations to less regulated countries. The systenn's favorable treatment of income earned by foreign subsidiaries would facilitate such moves. A rapid deduction for pollution control is therefore necessary to provide equal treatment to companies not taking advantage of the foreign tax credit provisions. ${ }^{93}$

While Blum attacks Surrey's classification as overbroad, his own is too narrow: by including only those provisions that lack any tax-policy justification, Blunn's classification does not sufficiently recognize the subsidy function of many tax provisions. For example, Blum complains that the exclusion of a portion of net capital gain ${ }^{94}$ deserves analysis on taxpolicy grounds, and should not be considered a government subsidy program. ${ }^{95}$ Subsidy arguinents, though, play an important role in the debate over the capital gain exclusion. Timber growers and venture capitalists have advocated retaining the capital gain exclusion because their particular activities deserve favorable treatment, and not because of general taxpolicy considerations about taxing capital assets. ${ }^{96}$

Academic criticism of the Surrey definition thus comes from several directions. Some, like Professor Andrews, agree with the idea of defining tax expenditures as departures from a normative tax, but disagree with Surrey on which normative tax to choose as the baseline. Such criticism is devastating because it precludes the establishment of a umform, agreed-upon tax expenditure list. Others, like Professor Bittker, reject the tax expenditure concept as nothing more than a list of departures froin a normative tax specified by each author of a tax expenditure list. This fundamental argument against the concept draws support from the arbitrary content of any normative tax.

Consider the case of capital gains. What is the normative income tax treatment? One can make a plausible case for any of the following, or

92. I.R.C. $\$ 169$ (1982).

93. I do not mean to endorse these arguments, but only to point out that one can defend the pollution control equipment provision with tax-policy arguments.

94. I.R.C. § 1202 (1982), repealed by 1986 TRA, Pub. L. No. 99-514, § 301, 100 Stat. 2085, 2216-17.

95. Blum, supra note 87 , at 490 .

96. See H. Canham \& J. Gray, Federal Income Tax Change and the Private Forest SECTOR 6 (1986) ("Most nations offer special tax provisions . . . to encourage private forest owners to manage their lands in the public interest."). 
for something in between: taxation upon realization of gain, with an inflation adjustment; taxation upon reahzation, without an inflation adjustment; taxation upon accrual, with an inflation adjustment; or taxation upon accrual, without an inflation adjustment. Writing when there was a deduction for $60 \%$ of net capital gain, 97 Surrey opted for taxation upon realization, without an inflation adjustment, ${ }^{98}$ which is now the law. ${ }^{99}$ The thrust of the tax expenditure concept is that departures from the chosen norm are deemed mere subsidies-functional equivalents to direct spending programs. But a departure from an arbitrary norm can be viewed not as disguised spending, but as an expression of an alternative norm, or simply as an undesirable rule.

Other commentators, like Professor Blum, argue that it does make sense to characterize certain tax provisions as spending programs, but only those provisions that everyone recognizes as disguised spending programs. This approach greatly restricts the tax expenditure list, and is also subject to attack for its rehiance on an assumed consensus of experts. ${ }^{100}$

Although criticism of the tax expenditure concept is neither uniform nor unanimous, it is telling, and it suggests that Congress's nonacceptance of the tax expenditure concept ${ }^{101}$ should come as no surprise. The criticism also indicates the need to reformulate the tax expenditure concept.

\section{The TaX Expenditure Concept's Influence on Policy}

The tax expenditure concept, despite its theoretical flaws, has substantially influenced the legislative process. The Budget Act requires inclusion of tax expenditures in the President's annual budget. ${ }^{102}$ Congressional staff also prepare annual tax expenditure lists for the budget- and tax-writing committees. ${ }^{103}$ These lists are now widely known and consulted.

Members of the tax-writing committees and their staffs have also become familiar with the basic points of tax expenditure analysis. When asked to comment on proposals for new tax expenditures, the Treasury

97. See I.R.C. $\S 1202$ (1982), repealed by 1986 TRA, Pub. L. No. 99-514, § 301, 100 Stat. at 2217.

98. See S. SURREY \& P. MCDaniel, supra note 6, at 198-99, 208-09.

99. See I.R.C. $\S 1001$ (a) (1982).

100. See supra notes $87-93$ and accompanying text.

101. See infra notes $102-50$ and accompanying text.

102. 31 U.S.C. \& $1105(a)(16)(1982)$.

103. E.g., STAFF of Joint COMm. ON TAXation, 100Th CONG., 2D SESS., Estimates GF FedERAL TAX EXPENDITURes for FISCAL Years 1989-1993 (Comm. Print 1988) [hereinafter EsTIMATES OF TAX EXPENDITURES]. 
Department routinely suggests that providing subsidies through direct spending programs might be a better course than enacting new tax expenditures. ${ }^{104}$ Congress does not always heed this advice, but at least it hears it.

The "sunsetting" of several tax expenditure provisions ${ }^{105}$ suggests that Congress has partially accepted the arguinent in favor of treating tax expenditures like spending programs for purposes of budgetary review. Under a sunset provision, a tax expenditure automatically expires on a specified date unless renewed. The purpose of these provisions is to subject tax expenditures to periodic review analogous to that of direct spending prograins. ${ }^{106}$

Yet, Congress has made little progress in replacing tax expenditures with direct spending prograins. 107 Institutional forces are partly to blame, since tax expenditures and spending programs receive different treatment in both the executive and legislative branches.

In the executive branch, the Treasury Departinent draws up the tax expenditure budget for OMB review, but other agencies draw up the direct spending budgets. ${ }^{108}$ For exanple, the Department of Agriculture prepares budgets that include expenditures for agricultural diversion programs, but has no responsibility for tax expenditures relatimg to farmers. Agriculture, therefore, cannot propose a reduction in those tax expenditures in exchange for increased spending on farm programs.

Congress likewise gives tax expenditures and spending programs divided treatınent. Budget and appropriations committees fix the level of direct spending in each budget category, but set no limit on the amount of iax expenditures in particular prograin areas. Rather, the budget process gives the tax-writing committees a maximuin revenue total, which the cominittees can meet by any coinbination of taxes and tax expenditures. ${ }^{109}$ While the tax-writing cominittees can trade tax expenditures off against tax rates, no cominittee can inake such a trade-off between tax expenditures and direct spending in a particular area. Moreover, no sin-

104. See, e.g., Miscellaneous Tax Bills VII: Hearing Before the Subcomm. on Taxation and Debt Management of the Senate Comm. on Finance, 96th Cong., 2d Sess. 246-53 (1980) (statement of John M. Samuels, Tax Legislative Counsel, Department of Treasury) (suggesting adoption of nontax-based assistauce to railroads in lieu of proposed tax-exempt bonds, an inefficient method of providing subsidy).

105. E.g., I.R.C. $\S 41($ h)(1) (Supp. IV 1986) (termination of research and development credit on December 31,1988$)$.

106. See Staff of Joint Comm. on Taxation, 99th Cong., 2D Sess., General ExplanaTION OF THE TAX ReForm ACt OF 1986, at 130 (Comm. Print 1987) [hereinafter Bluebook].

107. See infra notes 133-37.

108. See OMB, Budget of the United States Government, Fiscal Year 1989, at 6e-2 (1988).

109. See S. SURREY \& P. MCDANIEL, supra note 6, at 47. 
gle committee could decide to replace a tax expenditure with a direct spending program, unless the direct spending program happened to be within the jurisdiction of the Ways and Means Committee or the Finance Committee.

This variance in treatment between tax expenditures and direct spending programs makes it difficult, if not impossible, to coordinate tax expenditure and spending policy. Without institutional reform, merely demonstrating the inappropriateness of a tax expenditure will lead to no change.

Institutional problems aside, evidence also indicates that Congress has not taken the tax expenditure concept fully to heart. Many Members of Congress (as well as Presidents Reagan and Bush) apparently regard tax expenditure repeal not as a decrease in spending, but as an increase in taxes. 110 Two major pieces of legislation, the Tax Reform Act of 1986 (1986 TRA) ${ }^{111}$ and the Gramm-Rudman-Hollings Act, ${ }^{112}$ illustrate the gap between Surrey's analysis and actual practice on the Hill.

In the process of enacting the 1986 TRA, both the administration and the tax-writing committees failed to address the point that many provisions slated for repeal fulfilled inportant subsidy functions that would need to be performed outside the tax system if the relevant tax provisions were repealed. In its November 1984 report to the President on tax reform, the Treasury Department sidestepped the tax expenditure issue by denying that its recoinmendation to repeal various tax provisions implied that none of the tax-preferred activities deserved direct public support:

Such a judgment would go beyond the mandate from the President to propose reforms that will make the tax system broad-based, simple, and fair. Except in a few cases this study makes no recommendations about the need to enact spending proposals to replace subsidies currently administered through the tax system. Of course, to the extent that direct spending replaces tax subsidies, tax rates could not be reduced as much as proposed. ${ }^{113}$

The administration, though, ignored the suggestion that it consider direct spending alternatives.

The tax-writing committees repealed or cut back a number of tax expenditure provisions without replacing them with direct spending programs. ${ }^{114}$ The committee reports justified these repeals on various tax-

110. See infra note 139 and accompanying text.

111. Pub. L. No. 99-514, 100 Stat. 2085.

112. Balanced Budget and Emergency Deficit Control Act of 1985, Pub. L. No. 99-177, 99 Stat. 1037.

113. TREASURY I, supra note 14 , at 20 .

114. The 1986 TRA repealed the following tax expenditures without providing any direct expenditure replacement: all capital gains provisions, I.R.C. $\S 1202$ (1982), repealed by 1986 TRA, Pub. 
policy grounds, giving no indication that Congress had determined, as a matter of spending priorities, that federal support was unwarranted.11s

L. No. 99-514, § 301(a), 100 Stat. at 2216; special taxable income deductions for life insurance companies, id. §806(a), repealed by Pub. L. No. 99-514, §1011(a), 100 Stat. at 2388; deductions for property and casualty insurance companies' unpaid losses, $i d$. $\S$ 832(b)(5)(A), (๑), amended by Pub. L. No. 99-514, $\S 1023(a), 100$ Stat. at 2399 (discounting required); deductions for protection-againstloss accounts of mutual property and casualty insurance companies, id. $\S 824$, repealed by Pub. L. No. 99-514, §1024(a)(1), 100 Stat. at 2405; expensing of construction-period interest and taxes for low-income housing, id. $\S 189$, repealed by Pub. L. No. 99-514, § 803(b)(1), 100 Stat. at 2355; the investment tax credit (other than for rehabilitation, reforestation, and energy investments), $i d$. $\S \S 46-48$, amended by Pub. L. No. 99-514, $\S 211,100$ Stat. at 2166-70; nonrecognition of gain on corporations' property distributions in liquidation, id. § 336, amended by Pub. L. No. 99-514, § 631, 100 Stat. at 2269-71; dividend exclusion, id. §116, repealed by Pub. L. No. 99-514, § 612(a), 100 Stat. at 2250; deductibility of nonmortgage interest in excess of investment income, id. $\$ 163(\mathrm{~d})$, amended by Pub. L. No. 99-514, $\$ 511(\mathrm{a}), 100$ Stat. at 2244-46; treatment of qualified finance lease as lease for tax purposes, id. §168(f)(8), amended by Pub. L. No. 99-514, § 201(a), 100 Stat. at 2121-37; percentage-of-taxable-income deductions for additions to bad debt reserves for mutual savings banks, domestic building and loan associations, and cooperative banks without capital stock organized and operated for nonprofit mutual purposes, id. § 593, amended by Pub. L. No. 99-514, $\S$ 901(b)(1), 100 Stat. at 2378; amortization of trademark expenditures, id. § 177, repealed by Pub. L. No. 99-514, § 241(a), 100 Stat. at 2181 ; special rules for discount coupon redemptions, id. § 466, repealed by Pub. L. No. 99-514, $\S 823(\mathrm{a}), 100$ Stat. at 2373; amortization of railroad grading and tunnel bores, id. $\S 185$, repealed by Pub. L. No. 99-514, § 242(a), 100 Stat. at 2181; exclusion of payments in aid of utility construction, id. $\S 118(\mathrm{~b})$, amended by Pub. L. No. 99-514, $\S 824(\mathrm{a}), 100$ Stat. at 2374; deductions for two-earner married couples, id. $\$ 221$, repealed by Pub. L. No. 99-514, $\S 131(a), 100$ Stat. at 2113; exclusion of untaxed unemployment insurance benefits, id. $\S 85$, amended by Pub. L. No. 99-514, $§ 121,100$ Stat. at 2109; credit for contributions to political candidates, id. § 24, repealed by Pub. L. No. 99-514, § 112(a), 100 Stat. at 2108. See also EsTimates of TAX EXPENDITURES, supra note 103 (calculating revenue losses from tax expenditures).

The tax expenditures cut included all provisions structured as exclusions or deductions. The value of these exclusions and deductions declined because of the 1986 TRA's reduction of the top marginal rate from $50 \%$ to $33 \%$ for individuals and $46 \%$ to $34 \%$ for corporations. This reduction affected the following provisions: the exclusion of interest income from private purpose tax-exempt bonds, id. $\S 103$ (1982 \& Supp. III 1985), amended by Pub. L. No. 99-514, §1301(a), 100 Stat. at 2602; the allowance of accelerated depreciation on real estate, id. $\S 168$, amended by Pub. L. No. 99$514, \S 201$ (a), 100 Stat. at 2121-42; the exclusion of unemployment compensation, id. § 85, amended by Pub. L. No. 99-514, $\S 121,100$ Stat. at 2109 ; the deduction of medical expenses, id. $\S 213$, amended by Pub. L. No. 99-514, $\S 133,100$ Stat. at 2116; and numerous others.

115. For example, congressional discussion of the repeal of the unemployment benefits exclusion did not recognize that the prior tax treatment of such benefits represented a subsidy, and thus did not explain why repeal of the subsidy was appropriate. See S. REP. No. 313, 99th Cong., 2d Sess. 46 (1986). Repeal of the political contributions tax credit was justified on the basis that a "significant percentage" of contributions would be made even without the credit, and that the IRS has difficulty verifying credit claims. See id. at 86 . In contrast, no justification was offered for the total elimination of federal aid for political contributions, see id., and no meaningful justification was offered for reducing the rehabilitation tax credits. See id. at 753 . The assertion that the rehabilitation credit would offset tax liability on a larger amount of income, given lower rates, see id. at 86, was correct, but irrelevant. This claimed offset only masked the political accommodation involved: the credit would be retained but reduced in order to limit the revenue loss. The alternative of placing the credit outside the tax system was not explored. The discussion of tax-exempt bonds, see id. at 825 28, recognized section 103's subsidy function, but neglected to consider whether a direct subsidy would be preferable. The 1986 TRA nevertheless restricted the section 103 subsidy in certain respects. In the case of private-activity bonds, this restriction was justified on the grounds that its 
For example, Congress justified its repeal of the state sales tax deduction by stating that the deduction complicated administration of and compliance with the tax laws, clashed with the tax treatment of nondeductible selective sales taxes, and violated the general principle that individuals may not deduct the costs of their personal consumption. ${ }^{116}$ The relevant committee report did not mention, however, that the sales tax deduction was part of a subsidy program for state revenue collection and, as such, furnished federal aid to a presumably worthy cause. ${ }^{117}$ As this omission exemplifies, Congress treated tax expenditures that it repealed or restricted in 1986 as erroneous departures from appropriate tax rules, rather than as subsidies. ${ }^{118}$

If Congress had treated those provisions as tax-based subsidy programs, that would have revealed the arbitrariness of repealing them without replacing them at least in part by direct spending programs. That the tax system implements a spending program surely does not mean the program deserves no federal support. Indeed, failure to consider direct spending alternatives may have been an important factor in blocking reform of tax expenditures that the 99th Congress considered repealing, but ultimately retained. In scrutinizing tax expenditures in areas where they considered some continued federal support appropriate, ${ }^{119}$ the tax committees faced a Hobson's choice: either retain the tax expenditure, perhaps in a restricted or more complicated form, thus failing to simplify the tax system; or repeal it and withdraw government support from a worthy activity. The best alternative-replacing the tax expenditure with a direct spending program, perhaps funded at a lower level一was, as a practical matter, unavailable because the President had not proposed it, and because it would involve the jurisdiction of other committees. ${ }^{120} \mathrm{Be}$ -

absence would have led to an inefficient subsidy and would have increased local governments' borrowing costs. See id. at 825 . Neither of these points would have applied if Congress had chosen to create a subsidy for certain private activity bonds outside the tax system, but the merits of such a subsidy were not discussed.

116. See id. at 56-57.

117. The drafters of the report presumably omitted this point because they had no effective response.

118. Congress was certainly aware of the subsidy cutbacks, but entertained no concrete suggestions to enact spending programs as replacements. For example, Senator Gorton (R-Wash.) stated: "[I]f we agree to cease using the Tax Code as an instrument of social policy, then we must either abandon the policy entirely, or face up to the need to pay for it by an explicit appropriation." 132 CONG. REC. S7528 (daily ed. June 16, 1986). He then suggested that proposed limitations on the deduction for passive losses would adversely affect low-income housing. Id. at S7528-29. However, he made no concrete proposal for averting this harm; he merely labeled the problem as something that "we are going to have to address." Id. at $\mathbf{S 7 5 2 9 .}$

119. E.g., I.R.C. $\$ 48$ (g) (Supp. IV 1986) (credit for building rehabilitation expenditures).

120. Moving the tax bill through just one committee was difficult enough. See generally J. BiRNBAUM \& A. MURRAY, supra note 17 (historical account of 1986 TRA's passage). 
cause of the undesirability of completely removing federal aid, many tax expenditures emerged relatively unscathed, ${ }^{121}$ and others were retained with complicated limitations. ${ }^{122}$ Congress's failure to repeal various tax expenditures generally reflected no express determination that the provisions were appropriate to the tax system; rather, the failure reflected the desire to continue benefits in the absence of nontax alternatives.

The treatment of charitable contributions of appreciated property provides a good example of a missed opportunity for reform. Under current law, a taxpayer contributing property to charity may generally deduct its entire fair market value.123 Thus, a taxpayer does better to contribute the property than to sell it and contribute the proceeds, since the former course avoids any tax on gain from the sale. In its November 1984 report on tax reform, the Treasury Department proposed limiting the deduction for charitable contributions of property to the property's adjusted basis. ${ }^{124}$ Such a provision would, in effect, characterize a contribution of appreciated property as a two-step transaction: a sale of the property to the charity at fair market value, and a contribution of the proceeds. Gain on the sale would be offset by a charitable contribution deduction in the amount of such gain, so the net deduction would equal the property's basis. Instead of requiring realization of the gain on such transactions, the Treasury Department simply proposed to limit the charitable deduction to basis, ${ }^{125}$ stating that without such a rule donors would never pay tax on their property's appreciation in value. ${ }^{126}$

Few would seek to defend the current rule, which allows a deduction for the fair market value of appreciated property, ${ }^{127}$ as an accurate measure of a donor's taxable income. The current provision's most serious problem is that it provides an incentive to overstate the value of con-

121. E.g., I.R.C. $\S 48(\mathrm{~g})$ (credit for building rehabilitation expenditures); id. § 48(a)(1)(f) (1982) (reforestation credit).

122. E.g., id. $\S 57(\mathrm{a})(6)$ (Supp. IV 1986) (treating unrealized appreciation on charitable contributions as preference item).

123. See id. $\S 170(\mathrm{a})(1)(1982)$.

124. See TREASURY I, supra note 14 , at $81-82$. The Treasury Department proposal would have allowed a taxpayer to deduct the lesser of adjusted basis or fair market value for donated property. However, the fair market value test would have applied only to property that had depreciated in value.

125. See id. Limiting the deduction to basis has the same general effect as requiring recognition of gain, except that the (implicitly recognized) gain is not included in adjusted gross income and accordingly does not affect such measures as the $2 \%$ of AGI floor on itemized miscellaneous deductions, I.R.C. $\S 67$ (a) (Supp. IV 1986), and the floor on medical deductions, id. $\S 213(b)(5)$. Treasury's proposal was simpler than a rule requiring gain recognition, since the proposal would not have required ascertaining the fair market value for appreciated property.

126. See TREASURY I, supra note 14, at 82.

127. I.R.C. $\S 170(\mathrm{e})(1)$ (Supp. IV 1986). 
tributed property. ${ }^{128}$ By making the value of donated property irrelevant, the Treasury proposal would have eliminated an important abuse and simplified administration of and comphance with the charitable deduction provisions. Of course, the proposal would also have discouraged charitable contributions of appreciated property, probably reducing the total volume of contributions. To maintain the level of government subsidy to charity, Congress or the administration could have proposed a non-tax-based subsidy program or a tax provision such as a credit for charitable contributions in excess of a specified percentage of adjusted gross income. Such a provision would have brought about a net simplification, since it would not depend on valuation of any property.

Rather than considering such alternatives, the administration dropped the Treasury proposal in response to heavy lobbying. ${ }^{129}$ That did not end the matter, however. Aware that the deduction for the fair market value of donated property allowed donors of appreciated property to escape tax on gain, but unwilling to harm charities, the tax-writing committees compromised by limiting the charitable contribution deduction to basis for minimum tax purposes, but not for regular tax purposes. ${ }^{130}$ This change subjected persons paying the minimum tax to the Treasury Department's proposed rule. Although the change will arguably simplify tax administration for some, on balance it cannot be regarded as a simplification; ${ }^{131}$ the whole idea of an alternative minimum tax is antithetical to simplicity. In any event, the change did not even approach the simplicity of the Treasury proposal. It is instructive that the stumbling block to such reform was not disagreement over the appropriate tax rule, but a commitment to subsidizing charitable contributions-a purpose best served by an alternative provision.

In only one instance did the 1986 TRA substitute a direct expenditure for a repealed provision. Congress eliminated the itemized deduction for expenses of adopting children with special needs, ${ }^{132}$ and amended the Social Security Act to provide federal spending support for

128. See TREaSURY I, supra note 14 , at $81-82$.

129. See R. Reagan, The President's Tax Proposals to the Congress for Fairness, GROWTH, AND SIMPLICITY 27 (1985).

130. See I.R.C. $\$ 57(a)(6)(A)$ (Supp. IV 1986) (defining tax preference for charitable contributions of donated property, for alternative minimum tax purposes, as amount of appreciation from basis). The minimum tax is complicated; calculated on an expanded income base, the tax applies only if it would exceed the regular tax. It is structured to apply only to wealthy taxpayers. See id. $\S 55$.

131. The provision complicates tax planning because, for example, many taxpayers will not know until the end of a given tax year whether they are subject to the regular tax or the alternative minimum tax. See $i d$. $\S 55$ (a) (minimum tax applicable only if tentative minimum tax exceeds regular tax).

132. 1986 TRA, Pub. L. No. 99-514, $\S 135$, 100 Stat. 2085, 2116 (repealing I.R.C. $\S 222$ (1982)). 
such expenses. ${ }^{133}$ In justifying this action, the House committee report approved federal support for the expenses in question, but disapproved the practice of providing this support through the tax system; according to the committee, that approach provides less support to lower-income families than to upper-income families. ${ }^{134}$ The committee also indicated that the program would be better administered by agencies with responsibility and expertise in the area of special-needs adoption than by the IRS. ${ }^{135}$ Two facts facilitated the enactment of a direct expenditure substitute: the President's tax reform proposal had anticipated such an enactment, ${ }^{136}$ and the Ways and Means and Finance Committees had jurisdiction over the direct spending program. This jurisdiction enabled Congress to avoid the complexities of intercommittee coordination. In addition, a federal program already covered some expenses of caring for special-needs children, although not the adoption expenses. ${ }^{137}$ It was relatively simple to extend this existing program to cover an additional category of expenses.

Thus, the 1986 TRA's failure to treat tax expenditures as spending programs led to what were, in effect, spending cuts embodied in tax reform legislation. The same Congress's deficit-cutting legislation, however, produced the opposite result: the Gramm-Rudman-Hollings Act ${ }^{138}$ mandated cuts in various direct spending programs, but not in any tax expenditures, and this failure to deal with tax expenditures is a serious flaw. While Gramm-Rudman severely cut most federal programs, it exempted all the spending programs that happened to be based in the tax code. This exemption of all tax expenditures from budget cuts in a time of fiscal restraint was as arbitrary as the 1986 TRA's wholesale, uncompensated-for repeal of a number of tax expenditures.

The exemption of tax expenditures from Gramm-Rudman suggests that many Members of Congress do not consider tax expenditures as spending provisions, and this attitude carried over into the 1987 deficit reduction negotiations. In the course of those negotiations, President Reagan adamantly opposed increasing taxes, calling instead for domestic spending cuts. ${ }^{139}$ The administration never proposed cuts in tax expendi-

133. Id; see BLUEBOoK, supra note 106, at 52-53 (Social Security Act amended to provide, as administrative expense, matching funds to parents for qualified expenses incurred for adoption of children with special needs).

134. See H.R. REP. No. 426, 99th Cong., lst Sess. 113 (1985).

135. Id.

136. R. REAGAN, supra note 129 , at 109.

137. See id.

138. Balauced Budget and Emergency Deficit Control Act of 1985, Pub. L. No. 99-177, 99 Stat. 1037.

139. See N.Y. Times, Nov. 10, 1987, at A20, col. 1. 
tures as a means of cutting domestic spending, since in its view that would have amounted to a "tax increase." The message that tax expenditures are spending and not tax programs is clearly not getting through.

Politicians commonly attack the tax expenditure concept for assuming that our money belongs to the government and that the government is doing us a favor by not taxing it. ${ }^{140}$ This criticism, of course, misses the point. Tax expenditure analysis does not assert that the federal government has a right to tax away everyone's income. Rather, it asserts that the government taxes to the extent of the normative tax, but gives back a substantial amount of this tax revenue through various tax-based spending programs. ${ }^{141}$ This assertion troubles politicians like Ronald Reagan because it seems to legitimate a high level of taxes and government expenditures. These politicians would much rather view a tax preference as equivalent to a low tax rate. In their view, tax reform that replaces tax preferences with lower rates seems like a relatively neutral step: the bottom line-namely the tax liability of high-bracket taxpayers who take advantage of preferences-stays the same.

By contrast, viewing a tax preference as a government spending program threatens conservatives. This view suggests that a taxpayer can lose his subsidy to someone else, leaving him high and dry, and paying a substantial rate of tax. For example, if one views the tax exemption for state and local bond interest as a tax expenditure, repealing the subsidy would justify no reduction in a bondholder's tax rate. Rather, repeal would require maintaining the tax rates where they were and using the added revenue to provide a non-tax-based subsidy to state and local governments. Tax expenditure analysis suggests that the 1986 TRA gave the wealthy a large tax cut in the form of reduced rates funded by repeal of various subsidy programs. Yet, the distributional tables used to analyze the 1986 TRA, in effect, take the opposite view that tax preferences are tax reductions for those taxpayers claiming the preferences on their returns. ${ }^{142}$ Indeed, politicians often prefer to view tax preferences as an appropriate way to reduce the burden on taxpayers who would otherwise be hard hit by the highest rates of the tax code. Certain tax expenditure provisions seem to support this view. For example, one can argue that preferential treatment of capital gains is not equivalent to a government

140. See H. Wells, Remarks at the Meeting of the Business and Commerce Political Action Committee (Feb. 20, 1986) (made upon receiving Business Leader of the Year Award) ("[S]ome personal tax deductions including interest paid on home mortgages are being referred to as tax expenditures ... . indicating the idea, it's the government's money that they are expending on you-a pretty scarey prospect for a country that believes in free enterprise and democracy."), reprinted in 132 CONG. REC. E899 (daily ed. Mar. 20, 1986) (extension of remarks of Rep. Bentley).

141. See supra notes 18-24 and accompanying text.

142. See Bluebook, supra note 106, at 16-17. 
program that taxes capital gains at a high rate but then provides a federal subsidy. Rather, such treatment simply reflects a government decision to tax capital gains at a low rate. ${ }^{143}$

The view that tax preferences are surrogates for low tax rates is, however, much harder to sustain in the context of a provision like the residential energy credit. As long as provisions like the capital gains deduction, which seem much more like abstinence from taxing than spending programs, are classified as tax expenditures, then this conservative view will hold substantial sway.

The failure of Gramm-Rudman and the 1986 TRA to treat tax expenditures as spending programs does not stem solely from errors in analysis. For various reasons legislators might have found it expedient to treat tax expenditures as tax, rather than as spending, provisions. Enactment of spending programs to replace some of the repealed tax expenditures would have diminished the rate reduction that made the tax reform bill so attractive to many legislators and to President Reagan. Moreover, lobbyists for groups favored by existing provisions that were slated for repeal often had no incentive to suggest direct spending alternatives. Any such proposal would have had bleak prospects, given the prevailing hostility to spending programs, even well-established ones. Fighting tooth and nail to protect existing tax provisions, or at least to minimize the damage, seemed the better course. Finally, although there were reasons why direct spending alternatives did not appear very practical in 1986, the fact is that hardly anyone on the Hill even thought about the possibility of direct spending programs.

In light of the repeated failure of the tax reform proposals immediately preceding the 1986 TRA to treat tax expenditures as spending programs, it is ironic that in his recent book review entitled Tax Expenditures and Tax Reform, Professor Karzon lauds these proposals for their tax expenditure analysis. ${ }^{144}$ Karzon apparently bases his praise on the fact that the proposed reforms corresponded fairly closely to the tax expenditure budget. ${ }^{145}$ Since this budget lists the tax system's departures from a normative income tax, it should not be surprising that a comprehensive tax reform proposal would call for the repeal of many items that happen to be listed as tax expenditures. No close correspondence exists, however, between the most comprehensive of the proposals

143. See Blum, supra note 87 , at 490.

144. See Karzon, Tax Expenditures and Tax Reform (Book Review), 38 VAND. L. Rev. 1397, 1398 (1985) (reviewing S. SURREY \& P. MCDANIEL, supra note 6) (success of tax reform stems from adoption of tax expenditure analysis); id. at 1400 ("[T] nently successful in shaping tax reform.").

145. See id. at 1403-06. 
considered in 1986 (Treasury I) and the tax expenditure budget. Numerous reforms proposed in Treasury I did not appear in the Fiscal Year (FY) 1985 tax expenditure budget, ${ }^{146}$ and many items in the tax expenditure budget were not slated for repeal by Treasury I. ${ }^{147}$ Moreover, tax expenditure analysis goes far beyond a call for the repeal of inappropriate tax provisions. It requires treating tax expenditure provisions as spending programs, asking whether they belong in the tax code and, if not, whether they should be implemented by another federal program or repealed. The tax reform proposals failed to perform this analysis. ${ }^{148}$

Thus, contrary to Karzon's assertion, ${ }^{149}$ the tax expenditure budget, and tax expenditure analysis in general, did not play a central role in the

146. Compare Treasury I, supra note 14 with OMB, Budget of The United States GovERNMENT, FISCAL YeAR 1985-SpeCIAL ANALYSES G-1 to -48 (1984) [hereinafter FY 1985 BUDGET, SPECIAL ANALYSES]. Affected items that do not appear in the FY 1985 tax expenditure budget include: indexing of interest income and deductions; indexing of basis for depreciation, inventories, and capital assets; modification of income taxation of trusts and estates; taxation of minors' unearned income at their parents' rate; miscellaneous estate and gift tax reforms; repeal of the exclusion for prizes and awards; limitation of the deduction for charitable contributions of appreciated property to basis; repeal of the charitable contributions deduction for non-itemizers; limitation of the deduction for entertainment and business meals; limitation of the deduction for travel expenses; repeal of the alternative minimum tax; repeal of the presidential campaign donation checkoff; increased limits on the amount of moving expenses deductible; restrictions on income averaging by full-time students; reduction of double taxation of corporate earnings distributed to shareholders; treatment of large partnerships as corporations; revision of the accounting rules for multiperiod production; and denial of interest deductions allocable to tax-exempt bonds carried by financial institutions.

147. Compare Treasury I, supra note 14 with FY 1985 Budget, Special ANalyses, supra note 146. Treasury I did not propose to repeal the following items listed as tax expenditures for FY 1985: exclusion of income earned abroad by U.S. citizens and certain federal employees, with limited exceptions; exclusion of income from foreign sales corporations; deferral of income of controlled foreign corporations; expensing of research and development expenses; credit for increasing research activities; deductibility of patronage dividends and certain other expenditures of cooperatives; deductibility of mortgage interest on owner-occupied homes; deferral of capital gains on home sales; exclusion of interest on state and local public-purpose bonds; the one-time exclusion of capital gains on home sales for persons age 55 and over; expensing up to $\$ 5,000$ of the cost of depreciable business property; carryover of basis of capital gains at death; amortization of business start-up costs; nonrecognition of gain on property distributed in liquidation; reduced rates on first $\$ 100,000$ of taxable corporate income; exclusion of interest on state and local debt for rental housing; exclusion of income from discharge of indebtedness; expensing of magazine circulation expenditures; deferral of gain on installment sales; deferral of income recognition under the completed contract rules; deferral of taxes on shipping companies; exclusion of payments in aid of utility construction; parental personal exemption for students age 19 and older; deductibility of charitable contributions; exclusion of employee meals and lodging; deferral of income by creating vacation pay reserves payable in later years; exclusion of public assistance benefits; exclusion of investments in individual retirement plans; deductibility of casualty and theft losses; deductibility of medical expenses; exclusion of untaxed social security benefits; and deferral of income from interest on savings bonds.

148. See supra notes $107-38$ and accompanying text.

149. See Karzon, supra note 144 , at 1404 (" $[\Pi] \mathrm{n}$ most instances the provisions targeted for change [by the major tax reform proposals] are recognized as tax expenditures."). 
1986 TRA. ${ }^{150}$ The unfortunate results were that reform was not nearly as comprehensive as it could have been and that federal support for many worthy activities was arbitrarily withdrawn.

It is revealing that reform proposals that miserably failed to incorporate tax expenditure analysis could nevertheless garner praise for such analysis. It demonstrates that many policymakers have forgotten Surrey's original message that tax expenditures are really not tax provisions at all. Instead, the tax expenditure list has, for many, become just a handy reference guide to possible tax reform targets. Surrey thus seems to have suffered a prophet's worst possible fate: his message has been accepted, but has lost its original vigor in the process. It is time to go back to basics and consider how the concept of tax expenditure can best contribute to tax-policy analysis.

\section{REDEFINING TAX EXPENDITURES}

\section{A. Introductory Comments.}

The tax expenditure concept is a powerful rhetorical tool, but a thorough reading of Surrey and his critics ${ }^{151}$ indicates that Surrey tried to accomplish too much with the idea. By defining tax expenditures as departures from a normative tax, Surrey tried to cover all tax reform questions with the tax expenditure umbrella, which he could do only with considerable forcing. Surrey thus applied the concept in a questionbegging fashion. His key assertion was that only spending policies, and not tax-related policies, can legitimately defend tax expenditures. As a result, provisions identified as tax expenditures become virtually indefensible. ${ }^{152}$ Classification of a particular provision therefore becomes critical, but Surrey made such classifications by ipse dixit. ${ }^{153}$ Perhaps it is Surrey's mode of argument- "tax expenditures are what I say they are" and "tax expenditures can only be analyzed in spending terms"- that has left politicians less than entirely convinced by tax expenditure analysis.

The question naturally arises whether a reformulated tax expenditure concept would be less subjective and independent of the idea of a "normative tax." As long as the definition of tax expenditures ties the concept to a subjective "ideal" income tax, a uniform list of tax expenditures cannot emerge.

150. See supra notes 113-18 and accompanying text.

151. See supra notes 56-101 and accompanying text.

152. S. SURREY \& P. MCDANIEL, supra note 6, at 81 ("A tax expenditure is a spending program and must therefore be analyzed in spending terms.").

153. See supra notes $69-76$ and accompanying text. 


\section{B. Professor McIntyre's Solution.}

Professor Michael McIntyre has suggested that a new methodology can alleviate the problem of defining tax expenditures, which arises in the absence of a consensus on the features of a normative tax. ${ }^{154}$ McIntyre argues that the tax expenditure concept has multiple purposes, and that the definition of a tax expenditure need not be the same for each purpose. ${ }^{155}$ The argument is sound, as far as it goes. The concept of tax expenditures attempts to solve problems, and it could well require a different definition for different purposes. McIntyre does not, however, offer a truly new definition that liberates tax expenditures from the search for an elusive normative tax. He suggests that a tax expenditure list could include every item arguably a tax expenditure under the traditional definition, or only those items defined as such by universal agreement. ${ }^{156}$ Although either of these approaches might work in some cases, neither gets to the heart of the problem. Both still rely on the idea of a normative tax, and will likely produce tax expenditure lists that are either too broad or too narrow to be useful.

\section{The Reagan Administration's Redefinition of Tax Expenditures.}

In 1980, Seymour Fiekowsky of the Treasury Department offered a redefinition of tax expenditures. He characterized his redefinition as consistent with Surrey's aim in developing the tax expenditure budget-to identify tax provisions that "affect the private economy in ways that are usually accomplished by expenditures."157 Fiekowsky thought that only tax "substitutes for programs financed by appropriated funds" should be considered tax expenditures. ${ }^{158} \mathrm{He}$ viewed tax expenditures as provisions allowing affirmative answers to both of two questions:

(1) Absent the particular provision, does the existing tax law provide a general rule by which the results of the transaction would determine the transactor's tax liability? ... [and] (2) ... [I]s it possible to formulate an expenditure program administrable by a cognizant government agency that would achieve the same objective at equal, higher or lower budgetary cost? ${ }^{159}$

154. McIntyre, A Solution to the Problem of Defining a Tax Expenditure, 14 U.C. DAvis L. REv. 79, 82 (1980).

155. Id. at 92 .

156. See id. at 88-89.

157. Address of Assistant Secretary of the Treasury Stanley S. Surrey to Money Marketeers, in New York City (Nov. 15, 1967), reprinted in DeParTMENT OF THE TREASURY, supra note 60, at 322, 323; see Fiekowsky, The Relation of Tax Expenditures to the Distribution of the "Fiscal Burden," 2 CAN. TAX'N 211, 213-16 (1980).

158. See Fiekowsky, supra note 157, at 215.

159. Id. 
Fiekowsky seems correct in beginning by identifying provisions that substitute for direct expenditure programs, since this step avoids the concept of a normative tax, but his formulation is problematic. The first part of his test is either redundant, formahistic, or both. It is redundant because any provision that could satisfy the test's second part will constitute an exception to a general rule. The general rule is simply what, if anything, would remain after repeal of the special provision. In some cases, special rules may totally govern an area, leaving no general rule if repealed. The test is formalistic because it requires that the general rule defining a tax expenditure be currently "existing," rather than implicitly contained, in the tax code. Fiekowsky argues, for example, that accelerated depreciation does not qualify as a tax expenditure because "absent the provisions that permit taxpayers to use certain accelerated methods in computing annual depreciation deductions, there is no income tax accounting rule in the United States income tax laws which would apply." 160 Accelerated depreciation does, however, mark a departure from section 167's "reasonable allowance" for the decline in value of property, even though the section does not apply to equipment currently placed in service and provides no specific depreciation schedule. ${ }^{161}$ Although this rule provides no schedule, one could certainly design a schedule to reflect a reasonable allowance for economic depreciation more accurately than does current law. Alternatively, one could argue that the depreciation method used for computing corporate earnings and profits ${ }^{162}$ and for "tax-exempt use" property ${ }^{163}$ is the "general rule," since this method was intended to reflect economic depreciation without any subsidy. ${ }^{164}$ One could treat the current accelerated depreciation provisions as an exception to this implicit general rule. This approach would avoid the absurd and arbitrary result of failing to treat special rules as tax expenditures because no general rule exists.

The second part of Fiekowsky's test, by requiring that a spending program achieve "the same objective" as a putative tax expenditure, proves unduly simplistic. What if the tax provision has several objectives, some of which a direct spending program could achieve, but others that a spending program could not? Does it make sense to think that a direct spending program could replace a tax provision if the program involves substantially higher administrative costs?

160. Id.

161. See I.R.C. $\$ 167$ (Supp. IV 1986).

162. Id. $\S 312(\mathrm{k})$.

163. Id. $\S 168(\mathrm{~g})$.

164. See Staff of Joint Comm. on Taxation, 98th Cong., 2D Sess., General Explanation of the Revenue Provisions of the Deficit Reduction Act of 1984, at 44 (Comm. Print 1984). 
These definitional problems aside, Fiekowsky was calling for a much more restricted list of tax expenditures than the Treasury Department's and OMB's tax expenditure budgets contained. For example, Fiekowsky argued that accelerated depreciation was not a tax expenditure. ${ }^{165} \mathrm{He}$ also excluded from his definition the preferential treatment of long-term capital gains: "[S]ince the affected transactions cut across all private sector activities and all classes of transactions in both physical assets and property rights in those assets, there is no sensible set of expenditure programs that could replace this inconsistent income tax accounting rule."166

Reagan administration officials, particularly Under Secretary of the Treasury Norman Ture, viewed the traditional concept of tax expenditures with hostility, and advocated removal of Accelerated Cost Recovery System (ACRS) deductions from the tax expenditure budget. ${ }^{167}$ The inclusion of ACRS in the tax expenditure budget embarrassed the administration, which had supported this substantial liberalization of depreciation allowances in the Economic Recovery Tax Act of 1981.168 Ture criticized the tax expenditure budget as misleading and even useless for policymaking. ${ }^{169}$ The administration, however, recognizing the statutory mandate to include tax expenditures in the budget, and also the reality that complete abandonment of the tax expenditure concept would have raised a congressional outcry, attempted to redefine tax expenditures to exclude ACRS, among other items.

The administration reformulated Fiekowsky's definition. Special Analysis G for the FY 1983 budget defined tax expenditures as follows: "For a provision to involve a tax subsidy, two conditions are necessary:-The provision must be 'special' in that it applies to a narrow class of transactions or taxpayers; and-There must be a 'general' provision to which the 'special' provision is a clear exception." 170 This definition, unlike Surrey's approach, purports to be objective: instead of using an ideal, and necessarily subjective, income tax to define tax expenditures, it uses the general rules of the current income tax as the norm.

165. See supra note 160 and accompanying text.

166. Fiekowsky, supra note 157 , at 215.

167. See Harstad, Treasury and OMB Clash on Tax Expenditure Concept, 13 TAX NotEs 1407 (1981).

168. See id. at 1408 (discussing arguments against inclusion of ACRS in tax expenditure budget).

169. See id. at 1407.

170. OMB, The Budget of the United States Government, Fiscal Year 1983-SpeCIAL ANALySES G-5 (1982) [hereinafter FY 1983 BuDGET, SPECIAL ANALySES]. The administration's choice of language may have stemmed from its desire to conform to the language of the Budget Act, 2 U.S.C. $\$ 622(3)$ (1982), which defines tax expenditures as "special" provisions. 
On closer inspection, however, this approach turns out to be just as subjective as Surrey's. Countless sets of rules can be characterized as the general rules of the current income tax, with other rules constituting the exceptions. One could reasonably say that section 61 states the general rule defining gross income, ${ }^{171}$ and that the various exclusions set forth in sections 101 through $134^{172}$ state exceptions to this general rule. FY 1983 Special Analysis G, however, did not adopt this view. For example, it did not consider section 102, which excludes gifts and inheritances from gross income, as an exception to the general rule of section 61; rather, it claimed that section 102 itself states the general rule that no gifts are included in income. ${ }^{173}$ Such reasoning would leave the tax code with relatively few "special" rules.

One might possibly extract from the current tax laws a minimum set of rules to define each person's tax liability and collectively specify a rational tax on net income. One could consider all other rules exceptions to these "general" rules. However, even if only one such minimum set of rules existed, it would not advance tax expenditure analysis because the reverse problem would arise: most of the tax code would consist of "special rules."

These problems with developing a set of objective general rules, as well as the absence of criteria for distinguishing "special" from "general" rules, show that the general/special dichotomy is as arbitrary and subjective as an ideal income tax. ${ }^{174}$ Both the current OMB approach and the Surrey approach identify tax expenditures as departures from a set of subjectively constructed "normal" or "reference" tax rules. The difference lies merely in the rules chosen as the baseline.

The second element of the FY 1983 Special Analysis G test-the requirement that a tax expenditure apply to a narrow class of transactions or taxpayers-appears to derive from the second part of Fiekowsky's test, which asks whether an asserted tax expenditure could be reformulated as a direct spending program. Special Analysis G for FY 1988 restates the test as whether "the particular provision applies to a distinctive class of transactions sufficiently narrow in scope that it could be replaced by an expenditure program administrable by a Federal

171. I.R.C. § 61 (1982 \& Supp. IV 1986).

172. Id. $\$ \S 101-34$.

173. FY 1983 Budget, SPecial ANAlyses, supra note 170, at G-6.

174. The administration has acknowledged that it is impossible to identify "special" rules in an objective manner: "[W]hile the distinction between the normal and special provisions of the income tax may be clear in the abstract, in practice there is always difficulty in applying the distinction in order to delineate tax expenditures." First Concurrent Resolution on the Budget, FY 83: Hearing Before the Senate Comm. on the Budget, 97th Cong., 2d Sess. 231 (1982) (statement of John Chapoton, Assistant Secretary of the Treasury for Tax Policy). 
agency other than the Internal Revenue Service."175 Although this restatement provides some additional guidance, it does not clarify how to determine whether a spending program could replace a tax provision. When a tax provision has multiple purposes, must the hypothetical spending program fulfill all of those purposes? Is a tax provision replaceable if the hypothetical spending program would involve greater administrative costs than the tax provision? In order to proceed, the inquiry requires greater guidance and sophistication.

\section{An Alternative Approach.}

1. In General. The appropriate definition of a "tax expenditure" depends on the definition's intended use. The chief purposes of tax expenditure analysis should be to facilitate the replacement of tax expenditures with non-tax-based programs and to guide budgetary choices between tax-based and non-tax-based assistance. To advance this purpose, I define a "substitutable tax provision" as a tax provision that can be replaced with a non-tax-based federal program that fulfills the current tax provision's purposes at least as effectively as does the current provision itself. ${ }^{176}$ This definition of substitutable tax provisions does not rely

175. OMB, Budget OF THE UNITEd STATES GovernMeNT, FisCAL YEAR 1988-SPECIAL ANALYSES G-4 (1987).

176. This definition corresponds to suggestions made by Blum and Fiekowsky. The idea of moving away from a normative income tax in defining tax expenditures has arisen in Australia as well. Although the Australian definition of tax expenditures does seem to presuppose some kind of benchmark tax structure, the definition also embodies an element of comparison to direct expenditures. Thus, the Australians define tax expenditures as "[r]eliefs or concessions in the tax system (not being a basic component of the tax structure) which reduce tax liability and have effect on the Government's budget similar to direct expenditures." See Australian Gov't Publishing SERV., ReForM OF THE AUSTRALIAN TAX SYSTEM: DRAFT WhITE PAPER xiii (1985). In specifying the benchmark tax structure, the system apparently does take into account whether the tax provisions in question are alternatives to direct expenditures:

[T] he aim of identifying taxation expenditures should be to include in the Budget-making process and documentation the cost of special taxation provisions which can, in most cases, be considered as alternatives to direct expenditure programs, rather than to attempt to define some ideal taxation system and show deviations from it.

Australian Gov't Publishing Serv., Budget Statement No. 4, at 265-66 (1982-1983).

In proposing this classification of substitutable tax provisions, I avoid calling them "tax expenditures." That term implies that all provisions classified as tax expenditures are "truly" spending programs and that provisions not so classified are not. I want to avoid the implication that substitutable tax provisions are necessarily completely equivalent to spending programs (i.e., that none of them has any possible tax-policy justification), or that provisions not classified as substitutable have no spending or subsidy aspects. The substitutable tax provision definition merely points out that certain tax provisions could be replaced by spending programs. Some of these provisions may have nothing to do with the tax system other than being located in the tax laws as a matter of legislative convenience or politics. Others may have some purpose related to the tax system. Moreover, many tax provisions that do not qualify as substitutable under the above definition perform subsidy functions and are analogous to spending programs in that sense. A dichotomy between "tax" and "spending" programs has a tendency to mislead. The classification of substitutable tax provisions is 
on the idea of a normative tax, and thus avoids attack from those who disagree with a particular normative tax or, more generally, with the approach of defining tax expenditures as departures from a normative tax. Concluding that a tax provision is substitutable does not imply that a spending program should be substituted. Policymakers can choose not to furnish any federal assistance, to maintain current law, or to revise the tax provision at issue. Classifying a provision as substitutable implies only that a hypothetical spending program would provide assistance at least as well as current law.

Classification under this scheme involves two steps: (1) identifying a provision's significant purposes, and (2) determining whether a nontax program can serve those purposes at least as well. Performing these steps will often require judgment; many tax provisions have multiple purposes, some of which are best carried out by a nontax program, and others that are best accomplished through the tax system. In some instances, it is a matter of opinion whether the advantages of a non-tax-based program outweigh the advantages of the current tax law provision, but in many others this determination will generate little controversy.

In cases involving potential disagreement, such as when a direct expenditure cannot exactly fulfill a tax provision's purposes, the classifiers must judge whether the advantages of the direct expenditure outweigh the disadvantage of not precisely fulfilling the purposes of current law. If the question is close, one should err in favor of classifying the provision as substitutable in order to enable the appropriate executive department and congressional committees to evaluate the arguably superior spending program.

Because the classification of substitutable tax provisions depends on policy analysis, which inevitably involves political considerations and personal value judgments, such classifications will never be indisputable. Yet, since the concept of substitutable provisions is simply a tool of policy analysis, this indeterminacy presents no real problem. The degree of indeterminacy is relatively modest in light of the narrow scope of the policy question involved, and falls well short of the indeterminacy that arises in classifying tax expenditures under the traditional tax expenditure definition. Moreover, any indeterminacy in the definition stems from the indeterminacy of the basic policy question at issue: can a given tax provision be replaced by a spending program?

Although the proposed list of substitutable tax provisions will include some items not currently listed on the tax expenditure list, such as

not intended to establish such a dichotomy, but simply to identify those tax provisions that could be replaced by spending provisions. 
the Presidential Election Campaign Fund Checkoff ${ }^{177}$ and subsidies contained in taxes other than the income tax, ${ }^{178}$ the list will likely be shorter than the current one. For example, it will not include accelerated depreciation on equipment. A non-tax-based subsidy, for several reasons, could not replace accelerated depreciation. First, a direct subsidy would involve greater administrative expenses than the current provision. Second, accelerated depreciation has the tax-related purpose of compensating, albeit crudely, declines in the real value of depreciation allowances by reason of inflation. Third, to the extent that accelerated depreciation was intended to benefit owners of capital equipment, a desire to reduce the tax on capital income provided the motivation for the provision. This implies that accelerated depreciation should provide no benefit to persons not subject to tax. ${ }^{179}$ The relative narrowness of the list of substitutable tax provisions is appropriate, given the list's purpose. It is simply unrealistic to hope that direct expenditures will replace the entire list of current tax expenditures. Indeed, a more modest list should make replacement more likely.

2. Classification of Particular Provisions. Determining a tax provision's substitutability requires identifying its significant purposes. The term "significant purposes" refers to purposes that are, or might be, publicly stated in a committee report. For example, the tax exemption for interest on municipal bonds ${ }^{180}$ has the purpose of reducing interest costs to bond issuers, and thus benefiting activities financed by such bonds. Although section 103 might also benefit investors in tax brackets that exceed the "implicit tax" on bond interest, and almost certainly benefits bond counsel, Congress would view the benefits to upper-bracket investors and bond counsel as costs necessary to achieve section 103's purposes, rather than as ultimate goals. These benefits are not "significant purposes" of the tax exemption, but rather its "incidental effects."

An evaluation of direct expenditure alternatives to a tax provision should focus on whether a direct expenditure could deliver the same level of government support as the tax provision at equal or lower cost. Both administrative costs and compliance costs should factor into this evaluation, although the overall desirability of providing aid to the activity in question is not relevant. Thus, in the case of airport industrial development bonds, ${ }^{181}$ the question is simply whether the government could pro-

177. See I.R.C. $\S 6096$ (1982 \& Supp. IV 1986). This provision is presumably not listed as a tax expenditure because it involves no revenue loss.

178. See infra pp. 1195-96.

179. See I.R.C. $\$ 168($ h) (Supp. IV 1986).

180. Id. \& 103.

181. Id. $\$ 142(\mathrm{a})(1)$. 
vide a direct interest subsidy at a cost equal to or lower than the revenue lost under the tax exemption, not whether the government should subsidize airports at all.

Applying the substitutable tax provision definition to some provisions in the current tax expenditure budget will illustrate how the definition works. Many provisions are easily identified as substitutable, mcludimg the credit for increasing research activities, ${ }^{182}$ the alternative fuel production credit, ${ }^{183}$ the alcohol fuel credit, ${ }^{184}$ the exclusion of interest on state and local government bonds, ${ }^{185}$ the mvestment credit for and seven-year amortization of reforestation expenditures, ${ }^{186}$ the tax credit for historic preservation, ${ }^{187}$ the low-income housing credit, ${ }^{188}$ and the targeted jobs credit. ${ }^{189}$

The targeted jobs credit, for example, currently provides a tax credit to employers for a specified percentage of wages paid to members of targeted disadvantaged groups for the first two years of employment. Eligibility for the credit requires certification of an employee by a local agency and submission of a certification voucher to the employer before the employer hires the employee or withm a short time thereafter. ${ }^{190}$ The einployer claims the credit on its income tax return. A direct expenditure alternative could involve a direct payment, equal to the current tax credit, to the employer from the Department of Labor. The certification procedure could renam unchanged. ${ }^{191}$ Alternatively, the government could make payments directly to the employee. This approach would avoid one problem under current law: a potential employee's meinbership in a targeted group often discourages employers from hiring him, despite the financial imcentive. For example, one targeted group under current law consists of "economically disadvantaged ex-convict[s]." 192

182. Id. §41; see OMB, BUdget of the UNITED STATES GovernMeNT, Fiscal YeaR 1989-SPECIAL ANALYSES G-36 (1988) [hereinafter FY 1989 BUDGET, SPECIAL ANALYSES].

183. I.R.C. § 29; see FY 1989 BUDGET, SPECIAL ANAlySES, supra note 182, at G-36.

184. I.R.C. $\S 40$ (West 1988); see FY 1989 BUDGET, SpECIAL ANALYSES, supra note 182, at G36.

185. I.R.C. $§ 103$ (Supp. IV 1986); see FY 1989 Budget, Special ANAlyses, supra note 182, at $\mathrm{G}-37$ to -40 .

186. I.R.C. $\S \S 48(a)(1)(F), 194$ (1982 \& Supp. IV 1986); see FY 1989 BUDGET, SPECIAL ANALYSES, supra note 182 , at G-37.

187. I.R.C. $\S 48(\mathrm{~g})$ (Supp. IV 1986); see FY 1989 BudGET, SPECial ANAlySES, supra note 182, at G-38.

188. I.R.C. § 42; see FY 1989 BUdGET, SPECIAl ANAlyses, supra note 182, at G-38.

189. I.R.C. $§ 51$ (West 1988); see FY 1989 BUDGET, SPECIAI ANALYSES, supra note 182, at G39.

190. See I.R.C. \& 51(d)(16) (Supp. IV 1986).

191. The procedure is already supervised by the Labor Department, not the Internal Revenue Service. See id. $\S 51(d)(15)$.

192. Id. §51(d)(7). 
Understandably, many persons who fit this description may be unwilling to truinpet that fact in a job interview. Changing the prograin to pay employees directly, however, is not critical in identifying the targeted jobs credit as substitutable. Either direct expenditure alternative described above would accoinplish the purposes of current law at least as well as the current tax credit; accordingly, the current credit is a substitutable tax provision.

In soine cases, identifying a provision as substitutable requires further analysis. For example, percentage depletion for oil and gas ${ }^{193}$ should be classified as substitutable in part. Percentage depletion allows a deduction of a specified percentage of the incoine froin oil and gas production; the taxpayer's cost basis in the oil and gas in question does not limit the total percentage depletion deductions allowed. Current practice treats the excess of percentage depletion over cost depletion as a tax expenditure. A inore accurate analysis would recognize that, under certain circuinstances, cost depletion as currently allowed ${ }^{194}$ nay not accurately reflect economic depletion of a taxpayer's reserves. ${ }^{195}$ Changing the rate of cost recovery could provide a deduction that accurately reflects econoinic depreciation. Percentage depletion that exceeds such a restructured cost depletion allowance serves to subsidize oil production (or, perhaps, to encourage energy self-sufficiency) - purposes that a non-taxbased subsidy for exploration, production, or some other aspect of energy self-sufficiency, such as alternative energy production or conservation, could accomplish. Thus, the current provision for percentage depletion could be replaced by a tax provision involving no subsidy purpose (restructured cost depletion) and a non-tax-based subsidy prograin. Such a provision constitutes a partially substitutable tax provision-substitutable to the extent that a non-tax-based prograin can replace it. Splitting the provision in this fashion clarifies the analysis.

The immediate deduction for research and development ( $R \& D$ ) expenditures ${ }^{196}$ presents an exainple of a provision with some purposes that a tax-based provision can best accomplish and others that a provision outside the tax system can best achieve. Section 174 allows businesses to deduct $R$ \& $D$ expenses iminediately upon incurring them

193. Id. § 613.

194. Id. § 611 (1982).

195. For example, suppose that a well has reserves estimated at $1,000,000$ barrels, that it is being depleted at a rate of 100,000 barrels per year, that the cost basis of the well is $\$ 614,460$, and that the cost of the well equals its value at a $10 \%$ interest rate. In that case, the value of the well at the end of the year will decline to $\$ 575,900$ (the present value of an annuity of $\$ 100,000$ for nine years), a decline in value of only $\$ 38,560$, while straight-line cost depletion would call for a recovery of $\$ 61,446$.

196. Id. § 174 (1982 \& Supp. IV 1986). 
rather than treating them as property development costs. ${ }^{197}$ The immediate deduction of these expenses avoids the need to distinguish between $\mathrm{R} \& \mathrm{D}$ and general business expenses, and only a tax-based provision can effectively accomplish this purpose. The simphicity gains of section 174, however, come at the price of income distortion. Alternatively, amortizing $R \&$ D costs over a specified period, such as five years, could produce an accurate measurement of economic income. Section 174's subsidy purpose could then be achieved by direct government grants, targeted toward research considered most important for society. Even nontargeted grants would prove superior to the current tax-based subsidy because their effect would not depend on the tax position of the taxpayer conducting R \& D. Arguably, though, distinguishing R \& D expenses from other business expenses involves such unpredictable and potentially enormous administrative problems that current law might provide the most efficient $\mathrm{R} \& \mathrm{D}$ subsidy. But this uncertainty should not prevent classifying section 174 as substitutable, which will occasion further study of the provision and the potential administrative difficulties with its replacement. In sum, while a scheme that requires capitalization and amortization of $R \& D$ expenses for tax purposes and subsidizes thein outside the tax system might be administratively more complex than current law, on balance it would arguably provide at least as efficient a subsidy for $\mathrm{R} \& \mathrm{D}$ as current law, and thus section 174 should qualify as substitutable.

The exclusion of income earned abroad by U.S. citizens ${ }^{198}$ furnishes an example of a provision, currently classified as a tax expenditure, that should not be classified as substitutable. Section 911 allows a taxpayer to exclude up to $\$ 70,000$ of income from personal services abroad, plus the excess of her housing expenses abroad over a base amount, provided that she meets foreign residence and other requirements. ${ }^{199}$ This U.S. tax preference ains in part to help U.S. companies employing U.S. personnel to compete with companies that employ foreign personnel, who typically do not pay tax on income earned abroad. Since this purpose amounts to a desire to relieve the tax burden on foreign-earned income, an exclusion from income tax, rather than a nontax subsidy, seeins most appropriate. The exclusion also seeks to compensate U.S. citizens for high foreign housing costs. The exclusion for excess housing expenses reflects a theory that the dollar value of such expenses overstates their consuinption value, since that dollar value reflects a higher overall price level than in the U.S. Moreover, employees of competing companies are not taxed

197. See id.

198. Id. § 911.

199. Id. 
on compensation that goes to pay these inflated housing costs. A taxbased provision best serves the purposes of the housing cost exclusion, since the exclusion relates to the determination of taxable income.

Concluding that the tax system best implements section 911 's benefits does not necessarily justify the exclusion. One can argue that the general exclusion is inappropriate, ${ }^{200}$ or that it inappropriately subsidizes conspicuous housing consumption and clashes with the general principle that the income tax ignores differences in regional price levels. Classifying section 911 as nonsubstitutable simply means that any reform of the section must proceed within the tax system, rather than merely replacing the exemption with a non-tax-based subsidy program.

\section{Implications of the Substitutable Tax PROVISION APPROACH}

\section{A. Institutional Reform.}

The concept of substitutable tax provisions should breathe life into the moribund tax expenditure budget. Confined to a "special analysis," the budget is merely an appendix to the President's budget. ${ }^{201}$ Until the budget integrates tax expenditures and direct spending programs in each budget category, ${ }^{202}$ Congress will not treat tax expenditures as spending programs, whatever the theory might say. Indeed, replacing tax expenditures with spending programs will not become standard practice until the budget-making process forces agencies with authority over spending programs to consider such replacement seriously. These agencies must design substitute spending programs long before Congress becomes involved. For this reason, Surrey and McDaniel argued that OMB should set total budgets, covering both tax expenditure and spending programs, for each agency, and then allow those agencies to allocate resources between the tax expenditure and spending programs. ${ }^{203}$ However, many tax expenditures (as currently defined) are not completely analogous to spending programs. They have purposes that only the tax system can effectively implement. ${ }^{204}$ Giving agencies other than the

200. See, e.g., Thuronyi, A Critique of the Tax Treatment of U.S. Workers Overseas, 10 TAX NoTES 979 (1980).

201. E.g., FY 1989 Budget, SPECIAL ANALySEs, supra note 182, at G-1 to -45 .

202. The description of the budget refers to tax expenditures by program function, see e.g., OMB, Budget of The UNITEd StATES GOVERNMENT, FisCAL YeAR 1985, at 5-113 (tax expenditures on health care); see also OMB, BudGeT OF THE UNITED STATES GOVERNMENT, FISCAL YEAR 1988, at 6d-9 (1987), but are not listed in the budget of each agency, see, e.g., id. at 6f-72 to -86 (Department of Health and Human Services), or in tables showing budgetary authority or outlays by function, see $i d$. at $6 \mathrm{~g}-15$ to $-16,6 \mathrm{~g}-32$ to -38 .

203. See S. Surrey \& P. MCDANiel, supra note 6, at 33.

204. See supra note 196 and accompanying text. 
Treasury Department jurisdiction over such provisions could lead to chaos by fragmenting the Treasury Department's authority to make what are essentially tax-policy decisions. For this reason, the Treasury Department would not, and should not, relimquish its jurisdiction over these provisions.

Consider, for example, the provision allowing farmers to use cash accounting, ${ }^{205}$ which is listed as a tax expenditure under the traditional definition. ${ }^{206}$ Cash accounting enables farmers to deduct the costs of raising plants and animals when these costs are incurred.207 This rule provides an exception to the general rule requiring businesses to defer deductions for input costs until the final product is sold.208 If the Department of Agriculture assumed responsibility for this tax expenditure, it might decide to replace cash accounting with a direct subsidy for production. However, the Treasury Department might conclude that, at least for small farmers who produce annual crops, the distortions and inequity of the cash accounting rule pale in comparison with the adininistrative burden that accrual accounting would impose on both taxpayers and the IRS. Because this judgment falls within the realin of tax adininistration and policy, the Treasury Department should make it. For tax expenditure provisions that have both tax-policy and subsidy aspects (and thus cannot be classified as substitutable), Surrey and McDaniel's suggestion that agencies other than the Treasury Department take responsibility will likely go unheeded. This problem arises from the traditional definition of tax expenditures.

By contrast, the definition of substitutable tax provisions isolates provisions for which agencies other than Treasury could easily assume responsibility. Treasury should have no objection to ceding jurisdiction over these provisions because, by hypothesis, nontax statutes can just as effectively achieve the provisions' purposes. Before OMB lists a provision as substitutable, though, Treasury should concur in the classification. Under such a scheme, the budgets of the relevant agencies should include the outlay-equivalent costs. The President's annual budget for each such agency should also recommend outlay-equivalent levels for substitutable tax provisions or propose and describe non-tax-based alternatives along with their recominended expenditure levels. These alternatives might take the form of government subsidy prograins, regulatory programs, insurance programs, loan programs, or whatever other programs seem appropriate. To meet the demands of double-entry book-

205. See Treas. Reg. $\S 1.162-12$ (as amended in 1972).

206. See FY 1989 Budger, SPECIAI ANALYSES, supra note 182, at G-20.

207. See Treas. Reg. \$ 1.162-12.

208. See id. $\S 1.471-1$ (1960). 
keeping, the budget's receipts side should show imputed receipts in the amounts necessary to fund the substitutable tax provisions. ${ }^{209}$ In addition, separate listings of substitutable tax provisions in each agency's budget would facilitate the proposal and consideration of direct spending alternatives for these tax provisions.

Instead of having just the Treasury Department and OMB create the tax expenditure list, each affected agency should review these provisions and decide whether to propose alternative programs. Although the agencies would likely propose nontax substitutes for many substitutable tax provisions, non-tax-based subsidies do not always work better than tax-based subsidies; the facts of each case will determine the best choice. Indeed, revisions of particular tax expenditures can often meet criticisms of the provisions. For example, converting exclusions or deductions to refundable credits can cure the problem of "upside-down" subsidies. ${ }^{210}$

An agency could also propose to repeal or limit a substitutable tax provision. Given a limited budget that would cover both substitutable tax provisions and non-tax-based programs within the agency's jurisdiction, the agency might often have a strong incentive to propose eliminating or cutting back particular substitutable tax provisions. ${ }^{211}$ Thus, identifying a tax provision as substitutable does not necessarily advocate the enactment of a direct spending substitute. Tax policy does not dictate appropriate funding levels for non-tax-based substitutes; only the budgetary process can determine those levels, and budgetary priorities may well require the elimination of any federal support.

If the appropriate congressional committees review such alternatives, that review might facilitate tax committee reform of current law because a substitutable tax provision's repeal or restriction would not necessarily mean the termination of $f$ deral assistance. Interested persons could direct their requests for funding not only to the tax-writing committees, but to the relevant appropriating or authorizing committee as well. To formalize this procedure, the tax-writing and appropriating and authorizing committees should agree to joint jurisdiction over substi-

209. The listing of imputed revenue receipts is suggested in S. SURREY \& P. MCDANIEL, supra note 6 , at 44 .

210. While the value of a deduction increases with a taxpayer's marginal tax rate and hence with income, a refundable credit is of equal value to all taxpayers.

211. Arguably, an agency seeking to maximize its budget would routinely do just that, anticipating no real danger of losing its tax subsidy. This problem is unavoidable, but it is much less serious than under the traditional tax expenditure list. Under the traditional list, an agency may well propose elimination of an item, knowing that legislators can defend the item with tax-policy arguments. In the case of a substitutable tax provision, however, there will be little reason, other than subsidy arguments, for keeping the provision in the tax laws. Moreover, if elimination of the tax provision "counts" for purposes of the relevant appropriating committee's budget total, there will be no assurance that the tax provision will be retained. 
tutable tax provisions. ${ }^{212}$ Under such a scheme, the Ways and Means and Finance committees would identify substitutable provisions, perhaps by including those substitutable tax provisions in the appropriating committees' budgetary totals for purposes of the concurrent resolutions on the budget and the reconciliation process. As tax expenditures are now defined, the Ways and Means Committee and the Finance Committee would never agree to cede jurisdiction over all tax expenditures. ${ }^{213}$ Although such agreement with respect to substitutable tax provisions would not come easily either, it might be possible, particularly if the executive branch takes the first step by involving agencies other than the Treasury Department in decisions on substitutable tax provisions.

\section{B. Non-income Taxes.}

The Federal government has developed official tax expenditure budgets only for the income tax, although it has made unofficial estimates for the estate and gift tax. ${ }^{214}$ The traditional approach to defining tax expenditures, by reference to a normative tax, proves even weaker for non-income taxes, since even less consensus on their normative content may exist than for the content of a normative income tax. In the case of special excise taxes of limited scope, Surrey and McDaniel concede that no normative provisions exist and that therefore no tax expenditures can be identified. ${ }^{215}$

Since the substitutable tax provision definition does not rely on a normative tax, it can apply to any tax, even an excise tax of narrow scope. For example, the exemption from the manufacturers' excise tax for sales to nonprofit educational organizations ${ }^{216}$ is substitutable because a direct federal grant to educational organizations could replace it. This grant could either take account of expenditures on taxed articles or could simply provide a flat subsidy. A flat subsidy would actually make more sense, since the excise taxes are intended to serve as user fees and either an exemption or a grant based on use would undermine that purpose.

212. One example of an agreement for joint exercise of jurisdiction over a tax subsidy provision appears in H.R. REP. No. 426, 99th Cong., 1st Sess. 193-95 (1985) (relating to Merchant Marine Capital Construction Fund).

213. For the same reason that the Treasury Department would not agree to cede jurisdiction over tax expenditures involving tax administration and policy issues, the tax-writing committees would also be unwilling to do so (and rightly so).

214. S. SURREY \& P. MCDANIEL, supra note 6, at 233-35.

215. See id. at 233.

216. I.R.C. $\S 4221$ (a)(5) (West Supp. 1988). The exemption does not apply to the taxes on coal, id. $\S 4121$, and gas-guzzling automobiles, id. $\S 4064$ (1982 \& Supp. IV 1986). See id. § 4221(a) (West Supp. 1988). 
Although most tax expenditures appear in the income tax, the possibility of identifying substitutable tax provisions located in other taxes provides the substitutable tax provision concept with another powerful justification. Sometimes identifying obscure provisions hidden in an excise tax will have greater effect than pointing out well-known income tax expenditures, particularly in countries that rely more heavily on excise taxes. In any event, the proposed definition enables uniform treatnent of substitutable provisions in both inconie and non-incone taxes.

\section{Identifying Federal Subsidies.}

Special Analysis $G$ of the President's annual budget should continue to identify tax expenditures as traditionally defined. Besides being useful, such a listing is required by the Budget Act. ${ }^{217}$ While separately listing tax expenditures and substitutable tax provisions may at first seent confusing, it should actually reduce confusion, since the traditional list of tax expenditures lunips together provisions whose purposes can be served by spending programs and provisions reformable only within the tax systent.

Listing traditional tax expenditures in the budget identifies tax provisions that, even if not reasonably replaceable with direct spending programs, provide support sinilar to that provided through non-tax-based subsidies. Throughout the budget process, Congress should be aware of all the assistance provided through the tax systen1. For example, in a time of spending retrenchment, Congress could cut tax-based subsidies along with direct spending programs, or could set direct spending levels in light of tax-based subsidies.

On the question of how to define the "traditional" tax expenditures to list, a broader concept of economic inconie along the lines of HaigSimons income ${ }^{218}$ might prove nore useful than the normative tax elaborated by Surrey. For purposes of evaluating the subsidy effects of tax law, a relatively consistent econonic concept seenis superior to a concept tempered by concerns of political and adninistrative feasibility. Thus, for example, while politics and administrability may preclude taxation of imputed housing income, the nontaxation of such income provides a subsidy to owner-occupied housing relative to other capital. Congress should bear this subsidy in mind when it considers other assistance programs for housing. Accordingly, Congress should consider requiring that Special Analysis $G$ list the cases in which current law departs fron Haig-Simons income, along with estimates of the resulting revenue

217. See 2 U.S.C. § 622(3) (1982).

218. See supra note 61 and accompanying text. 
loss. ${ }^{219}$ Under this approach, the budget should restate tax expenditures for prior years according to the new definition in order to enable comparisons over time. In terms of budget mechanics, Special Analysis G should contain a list of tax expenditures, defined as departures from Haig-Simons income. Substitutable tax provisions'would appear as outlays in each agency's budget, and the total amount of substitutable tax provisions would also appear as part of budgetary receipts.

\section{The Dichotomy Between "Tax" and "Spending" Provisions.}

1. In General. Traditional tax expenditure analysis claims that a dichotomy exists between "tax" and "spending" programs. ${ }^{220}$ Identifying substitutable tax provisions and, by extension, traditional nonsubstitutable tax expenditures, shows that this dichotomy is ultimately artificial for purposes of policy analysis. By definition, nonsubstitutable tax expenditure provisions involve both tax-policy considerations and the purpose of subsidizing or favoring a particular activity. This combination calls for the use of spending analysis to evaluate how effectively a tax expenditure accomplishes its subsidy purpose, and of tax-policy analysis to evaluate tax structure issues raised by the provision. ${ }^{221}$

For example, the charitable contributions deduction ${ }^{222}$ both subsidizes charitable contributions and serves various tax-related purposes. ${ }^{223}$ Spending analysis does not aid in evaluating arguments that justify this deduction as an appropriate part of the income tax structure, but such analysis contributes a great deal in evaluating the argument that "chari-

219. This is the approach taken by a Senate bill in the 100th Congress that defined tax expenditures as departures from Haig-Simons income. See S. 1709, 100th Cong., 1st Sess. $§ 101,133$ CoNG. REC. S12,840, S12,840 (daily ed. Sept. 25, 1987). The bill also provided an alternative definition of tax expenditures as departures from a consumption tax, id., 133 CONG. REC. at $\$ 12,840$, an approach that would be problematic because we have no consumption tax.

220. See S. SuRREY \& P. MCDANIEL, supra note 6 , at 3.

221. The point that both tax-policy analysis and tax expenditure analysis can apply to one provision has been made by McIntyre, supra note 154, at 93-101. Analysts often fall into the trap of analyzing a provision solely in tax or in subsidy terms. For example, Professor Natbony considers the section 174 deduction for research and development expenditures solely as a subsidy provision, without recognizing that it also fulfills the function of providing a cost recovery method for $R \& D$ expenditures and that, if section 174 were repealed, Congress would have to devise an appropriate cost recovery method. See Natbony, The Tax Incentives for Research and Development: An Analysis and Proposal, 76 GEo. L.J. 347, 348 (1987). Professor Natbony's failure to focus on the need for cost recovery also leads him to overstate the amount of section 174's subsidy as $34 \%$ for corporations. See id. at 404 . In fact, the subsidy is much smaller, since a proper measure of the subsidy compares the immediate deduction provided by section 174 with the present value of cost recovery deductions that would reflect the economic depreciation of $R \& D$ expenditures.

222. I would not classify this provision as substitutable.

223. One such purpose is equal treatment for taxpayers who contribute personal services to charity and taxpayers who contribute the fruits of personal services rendered to others. See Andrews, supra note 78 , at $347-48$. 
ties would suffer" if the deduction were repealed. For tax provisions with both tax-related and subsidy purposes, one must apply both taxpolicy analysis and spending analysis.

This approach reconciles the seemingly polar positions of Professors Surrey and Andrews on the charitable contributions deduction. Surrey considers the deduction an upside-down subsidy, not a proper part of the income tax, ${ }^{224}$ while Andrews calls it an appropriate "elaboration of an ideal personal tax base."22s One might better evaluate a given argument in favor of the deduction with the type of analysis that argument suggests. The argument that the deduction forms a proper part of the tax base is a tax-policy argument, which does not call for spending analysis. On the other hand, the provision's tax-policy justification does not necessarily make spending analysis inappropriate; the deduction's subsidy effects provide an important argument for maintaining the provision. While analyzing the deduction under this approach might prove more complicated than either Professor Surrey or Professor Andrews would prefer, this complexity seems inevitable when a provision has various justifications, no single one of which is adequate by itself.

This approach also makes apparent the artificiality of the dichotomy between "tax" and "spending" programs. Before Surrey invented the concept of tax expenditures, tax provisions appeared fundamentally different from spending programs. ${ }^{226}$ Any curtailment of favorable tax provisions was a "tax increase" (as opposed to a spending cut)—as much of an anathema as an increase in marginal tax rates. Surrey rightly argued that tax provisions should not be immune from the type of analysis applied to spending programs, and that cutbacks of certain tax subsidy provisions would more closely resemble a decrease in direct subsidies than an increase in tax rates. ${ }^{227}$ But he overcompensated for others' errors by characterizing all tax expenditures as pure spending provisions to which tax-policy arguments could not apply.

2. Distribution of the Tax Burden. As part of the tax legislative process, tax-writing committees routinely consider tables showing the distribution of proposed tax changes among income classes. ${ }^{228}$ These

224. See S. Surrey, supra note 1 , at 223-32.

225. Andrews, supra note 78 , at 314-15.

226. Many people still think this way. See supra notes $107-43$ and accompanying text.

227. See supra notes $19-23$ and accompanying text.

228. E.g., S. REP. No. 313, 99th Cong., 2d Sess. 34 (1986) (showing percentage change in income tax liability by income class after passage of bill); STAFF of JOINT COMM. ON TAXATION, 97Th ConG., 1st Sess., General Explanation of the Economic Recovery Tax act of 1981, at 23 (1981) (showing projected revenue loss (as against prior law) from income tax reductions for two-earner married couples for FY 1982-1984). 
tables typically present the average tax increase or decrease for taxpayers in each income class. Presumably, the committees seek to ascertain whether proposed changes will treat income classes fairly, relative to each other.

The distributional effect of tax legislation is important, but recent congressional analysis of distributional data has been sloppy and misleading. One problem is that the tables often reflect percentage changes in tax liability, rather than percentage changes in after-tax income. The latter figures more correctly indicate the effect of tax changes on income distribution, since that distribution is expressed in after-tax terms. To keep income distribution constant, a tax change would have to effect the same change in after-tax income for all income groups. Under a progressive income tax system, though, a bill that cuts all taxpayers' tax liability by an equal percentage would not maintain the system's progressivity; the bill would cause a larger increase in the after-tax income of the wealthy. Yet, the legislative process has retained its focus on percentage changes in tax liability, perhaps because this focus makes tax legislation look more progressive than it really is.

With no more information than the average tax liability and income in each income class, one can create distribution tables that show percentage changes in after-tax income, assuming that the tax change in question does not change incomes. But this assumption may not be valid; tax changes usually change the distribution of pre-tax income and wealth. Accordingly, to obtain an accurate picture of the distributional effects of tax legislation, one must identify at least the most important effects of the legislation on the pre-tax wealth and income distribution.

For example, suppose Congress considers eliminating the targeted jobs tax credit 229 and reducing rates to keep the distribution of the tax burden the same as before the change. Assume, for simplicity, that predominantly wealthy taxpayers take the credit. The distributional tables as currently prepared would show no change in the tax burden distribution. However, if analysis of the proposed change takes account of the effect on incomes, and if one assumes that the tax credit functions as a wage subsidy and that wages would decline by the amount of the credit if it were eliminated, the tables would show a drop in the incomes of workers who benefited from the credit and an increase in their employers' pre-tax incomes.

Thus, in the case of the targeted jobs tax credit, one can relatively easily ascertain the effect of a tax change on pre-tax (and, consequently, after-tax) incomes, although the assumptions made above may not be

229. See supra notes $190-92$ and accompanying text. 
entirely accurate. With other tax changes, however, effects on pre-tax income distribution may prove difficult or impossible to ascertain. This Article cannot offer a solution to this fundamental public finance problem, but even recognizing the problem should suggest that considering solely the changes in taxes paid will often lead to error.

Professor McDaniel advocates an alternative approach to this problem. He suggests preparing tax burden distribution tables that show amounts of tax liability without adjusting for tax expenditures. ${ }^{230}$ Under his view, tax expenditures should not appear on tables that show tax burdens because tax expenditures are spending programs, which generally do not appear on tax burden tables. In the targeted jobs credit example, McDaniel would probably treat the amount of tax paid before the proposed change as taxpayers' liability unreduced by the targeted jobs credit. The distribution tables would thus show a reduction in taxes paid in the top brackets as a result of the change. The same outcome results when one considers the change in after-tax incomes. In other cases, however, McDaniel's approach would produce a misleading result. Suppose, for example, that Congress repealed the deduction for home mortgage interest, and reduced tax rates to keep the amount of tax in all income classes the same. Under current practice, the distribution tables would show no change. A comparison of after-tax income, too, would show little or no change. Under McDaniel's approach, however, the tables would show a sharp reduction in tax for wealthier taxpayers, since the pre-change tax burden would not reflect the deduction for home mortgage interest.

McDaniel considers this result appropriate because it correctly identifies the change in "tax"-considering the deduction for home mortgage interest not as a reduction in tax, but as a spending program. ${ }^{231}$ This line of reasoning epitomizes the artificiality of a distinction between "tax" and "spending" programs. Analyzing the effect of one type of government program in isolation, and focusing only on "tax" changes, is likely to be misleading in many cases. Both tax and spending programs affect the distribution of after-tax income, and, for this reason, those concerned with the equity of that distribution must consider the combined economic effect of all government programs.

3. Foreign Tax Credit. The foreign tax credit also illustrates how artificial it is to distinguish "tax" and "spending" provisions. Section 901 currently provides a U.S. tax credit for the amount of income tax

230. See McDaniel, Identification of the "Tax" in "Effective Tax Rates," "Tax Reform" and "Tax Equity," 38 NaT'L TAX J. 273, 275-76 (1985).

231. Id. at 277. 
paid to a foreign country, subject to specified limitations. ${ }^{232}$ Suppose that a foreign country's corporate tax rate is $34 \%$, the same as the current corporate rate in the U.S. ${ }^{233}$ Consider two cases. In the first, corporation $X$ earns income of 100 in country $A$, but under special provisions in $A$ 's tax law, $X$ owes foreign tax of only 24 , leaving it with after-foreign-tax profits of 76. In this case, $X$ will have U.S. tax liability of 34 , less a credit of 24 , for a net liability of 10 . In the second case, country $B$ provides a non-tax-based subsidy of 15 for corporation $Y$ 's operations, resulting in a total operating income of 115 . Since foreign tax applies to the entire amount, $Y$ owes foreign tax of 39, leaving it with the same after-foreign-tax profits as $X, 76 . Y$ has no U.S. tax liability, because the foreign tax credit wipes out its liability entirely.

Treating $X$ and $Y$ differently for U.S. tax purposes makes little sense. The difference in tax treatment penalizes companies like $X$, and provides an incentive for countries to restructure their tax systems by increasing the amount of "tax paid" in order to take advantage of the U.S. foreign tax credit, and to provide any desired investment incentives through non-tax-based subsidy programs.

While $X$ and $Y$ should clearly receive the same treatment, which treatment is appropriate remains uncertain. Should the U.S. allow $Y$ to receive a foreign tax credit for the entire amount of foreign tax paid, even though a portion of the tax revenues subsidizes the corporation? The foreign tax credit regulations deny a credit for taxes paid in exchange for a subsidy provided to a specific taxpayer, but allow the credit when the subsidy is generally available. ${ }^{234}$ These regulations effectively state that, under certain circumstances, the U.S. Treasury is willing to pay the cost of subsidies that U.S. taxpayers receive from foreign governments. One might rejoin that U.S. law should not allow a credit for a foreign tax to the extent that the foreign government uses the tax revenues to subsidize a taxpayer, but it is generally impossible to ascertain the extent to which a country subsidizes foreign corporations. For example, if a government subsidizes imports of concrete, but the price of concrete in the country is higher than the world price because of currency controls, does a subsidy exist?

An alternative approach, advocated by Professor McDaniel,235

232. I.R.C. $\S 901$ (West 1988).

233. See id. $\S 11$ (b) (Supp. IV 1986).

234. The foreign tax credit regulations deny a credit for foreign taxes paid in exchange for a specific economic benefit, but limit the definition of specific economic benefits to benefits "that [are] not made available on substantially the same terms to substantially all persons who are subject to the income tax." Treas. Reg. $\$ 1.901-2(a)(2)(i i)(B)(1983)$. Thus, a generally available subsidy would not be a specific economic benefit.

235. See McDaniel, supra note 230 , at 275-76. 
would be to treat $X$ and $Y$ alike by identifying the subsidy elements of the foreign tax law. This would require constructing a schedule of tax expenditures for each foreign country. How would one prepare such a list, though? Certainly, tax law provisions that have subsidy aspects extend beyond those here labeled substitutable tax provisions. Identifying the subsidy features of tax laws is an inherently doubtful exercise. ${ }^{236}$

As long as foreign countries make subsidies generally available, there may be no alternative to allowing a foreign tax credit. The shortcomings of this approach, however, suggest that the foreign tax credit's rationale is not as theoretically sound as generally assumed. That rationale focuses on the amount of "tax" paid to the foreign government in isolation from what the foreign government does with tax revenue, and under a broader view, the amount of "tax" paid seems a rather indeterminate concept, and hence the foreign-tax credit's theoretical underpinnings are weak.

4. Tax Expenditures and Constitutional Litigation. The Constitution prohibits various forms of federal or state assistance to private persons, including assistance that creates an establishment of religion. ${ }^{237}$ Governmental assistance to a private person engaged in racial discrimination may also constitute "state action" and thus allow a constitutional attack on that discrimination. ${ }^{238}$ As a result, discrimination suits sometimes implicate federal or state assistance in the form of preferential tax treatment.

According to Surrey and McDaniel, the underlying issue in all these situations is whether tax assistance is equivalent to direct assistance. If the answer is yes-and we contend that under rational governmental and judicial decisions it must be-a court need not search through the entire income tax system to determine which tax provisions involve government assistance. The tax expenditure list contained in Special Analysis G of the federal budget is a ready index to provisions that should be subject to the same constitutional restrictions as parallel programs financed by direct government spending. ${ }^{239}$

Under this view, courts should apply the definition of tax expenditures used for the tax expenditure budget in constitutional litigation. Tax expenditures, as equivalent to spending programs, should undergo the same constitutional analysis as government spending programs, while tax provisions not amounting to spending programs presumably should not un-

236. See supra notes $65-101$ and accompanying text.

237. U.S. CoNST. amend. I.

238. E.g., Burton v. Wilmington Parking Auth., 365 U.S. 715, 721-26 (1961).

239. S. SURREY \& P. MCDANIEL, supra note 6, at 119. 
dergo that analysis. Surrey and McDaniel temper the negative aspect of this argument by acknowledging that government financial assistance may exist "even though the item being litigated is not on the tax expenditure list."240 This results from the noncomprehensive quality of the tax expenditure list. ${ }^{241}$ Surrey and McDaniel do not, however, indicate how courts should decide whether a tax provision not listed in the tax expenditure budget is equivalent to a direct spending program.

In the context of constitutional litigation, merely stating that "the result should be the same for both [tax expenditures and direct expenditures]'242 does not advance analysis, since results vary even for seemingly very similar forms of direct assistance; the manner of providing aid makes a critical difference. For example, in Meek v. Pittenger, the Supreme Court held that while loans of instructional materials to private schools violated the establishment clause, loans of textbooks to children attending such schools did not, even though the schools placed the textbook orders and stored the books on their premises while the children were not using them. ${ }^{243}$

Instead of equating tax expenditures with direct spending programs, it would be better to acknowledge that various tax provisions provide various degrees of financial assistance. Courts can decide whether a particular tax provision that provides financial assistance violates the establishment clause (or constitutes state action or impermissible aid to racial discrimination) about as well as they can decide these issues with respect to a non-tax-based program.

As discussed above, a particular tax law provision can have multiple purposes, some related to tax policy and administration, and others that a direct spending program could achieve. ${ }^{244}$ In constitutional litigation, courts would do better to treat tax provisions as government programs often justified by hybrid purposes than to draw an artificial line between tax provisions that amount to spending programs and those that do not.

The Court's opinion in Mueller v. Allen ${ }^{245}$ is consistent with this approach. The case held that a Minnesota income tax deduction for tuition, textbooks, and transportation of dependents attending elementary or secondary schools did not violate the establishment clause. ${ }^{246}$ Parents of public school students could sometimes deduct expenses under this

240. See id. at 144.

241. See id.

242. Id. at 154 .

243. 421 U.S. 349,362 (1975).

244. See supra pp. 1190-91.

245. 463 U.S. 388 (1983).

246. Id. at 402-03. 
provision, but it primarily benefited parents whose children attended religious schools. ${ }^{247}$ In Committee for Public Education v. Nyquist, ${ }^{248}$ the Court had invalidated tax credits that reimbursed a portion of private school tuition expenses. The Mueller Court distinguished Nyquist on two grounds. First, Minnesota allowed the deduction to all parents, not just those with children in private schools. ${ }^{249}$ This distinction undoubtedly had some validity, although Justice Marshall had the better of the argument in pointing out that only about 100 of 815,000 public school students (those charged tuition for attending a school outside their district) received any substantial benefit from the deduction, while all students attending private schools benefited substantially from the deductions, and over $95 \%$ of these students attended sectarian schools. ${ }^{250}$ The Court also distinguished Nyquist on the ground that the Minnesota law involved a "genuine tax deduction," as compared with the credit in Nyquist. ${ }^{251}$ The Court offered only a cryptic explanation of this point, noting that the educational expenses deduction was "only one among many deductions - such as for medical expenses . . . and charitable contributions . . . available under the Minnesota tax laws"252 and concluding that "the Minnesota Legislature's judgment that a deduction for educational expenses fairly equalizes the tax burden of its citizens and encourages desirable expenditures for educational purposes is entitled to substantial deference."253

As the Court's reference to tax burden equalization suggests, it considered that the Minnesota deduction was motivated at least in part by tax-policy considerations unrelated to the goal of providing aid to private schools. ${ }^{254}$ For example, a person who incurs expenses for a dependent's education arguably has less ability to pay income tax than one with no such educational expenses. The deduction equalizes the treatment of persons who incur such educational expenses with the treatment of those who benefit from public education. In light of these considerations, the Court correctly distinguished the deduction in Mueller from the credit in Nyquist, which was available only to parents with children in private schools and apparently bore no relation to any concern with ability to

247. Id. at 391-92.

248. 413 U.S. 756 (1973).

249. Mueller, 463 U.S. at 398.

250. Id. at 405 (Marshall, J., dissenting).

251. See id. at 397 n.6.

252. Id. at 396.

253. Id.

254. However, as Surrey and McDaniel point out, the reference to encouraging desirable expenditures suggests a different motivation-providing a subsidy. See S. SURREY \& P. MCDANIEL, supra note 6, at 135 . 
pay income tax. ${ }^{255}$ The credit in Nyquist amounted to a tuition grant made through the tax laws and was designed to provide a "tax benefit ... comparable to, and compatible with, the tuition grant for lower income families." 256

To recognize this distinction between the Minnesota deduction and the credit in Nyquist, however, is not necessarily to agree with the result in Mueller. Despite this distinction, the Mueller provision's primary effect was to reimburse a portion of sectarian school tuition. Although the deduction had some tax-policy justification, the Court could have found that the provision had "the primary effect of advancing the sectarian aims of the nonpublic schools" 257 and hence held that it violated the establishment clause.

The Mueller case thus stands for the proposition that a tax provision justified at least in part by tax-policy considerations unrelated to advancing religion can survive an establishment clause challenge. ${ }^{258}$ Mueller illustrates the chronic shortcomings of analysis in this area. These shortcomings probably result from the nature of the applicable test: whether a provision's primary effect is to advance religion. This test should not depend on whether a court characterizes a provision as a "tax" or "spending" provision.

\section{CONCLUSION}

Ever since Stanley Surrey created the tax expenditure concept, it has proven extremely useful in alerting policymakers that the tax system provides subsidies. Yet, Surrey's original concept involved some simplification and failed to acknowledge that many tax code provisions resist neat classification as either "tax" or "spending" programs. As a result, the tax expenditure concept has not reached its full potential. In particular, Congress and the Executive have not fully integrated tax expenditures into the budget-making process.

The category of substitutable tax provisions proposed in this Article focuses on the possibility of replacing certain tax provisions with nontax programs. Such replacement can provide a number of benefits. First, it can simplify the tax laws, and true simplification-including outright de-

255. See Nyquist, 413 U.S. at 789-91.

256. Id. at 790 .

257. 463 U.S. at 396 (quoting Committee for Public Educ. v. Regan, 444 U.S. 646, 662 (1980)).

258. Under the facts of the case, however, this tax-policy purpose provided only weak support for the decision. The other distinction from Nyquist - the availability of the tax benefit at issue to all parents, not just those with children in private schools-is best viewed as a subset of the argument that the provision was a genuine deduction. If the deduction had only beeu available to privateschool parents, it would not have passed muster as genuine. 
letion of many substitutable provisions from the tax laws-is urgently needed. Second, it can provide federal support more efficiently and rationally. Owing to the structure of the tax laws, it often costs less to provide a given level of support outside the tax system. Substituting direct spending programs can therefore save money for the federal government, an urgent need in a time of fiscal stringency. Moreover, providing federal aid through the tax system often clashes with other federal programs. Removing these provisions from the tax code occasions review of their program goals. Finally, replacing tax expenditures with direct expenditures can facilitate budgetary review of substitutable tax provisions on the same basis as other spending programs. There is no reason to give automatic preference to provisions that happen to appear in the tax code.

This Article's proposal regarding substitutable tax provisions recognizes that no single definition of "tax expenditure" can serve all purposes. Surrey's traditional definition remains useful as a means of identifying tax-based subsidies, even though that identification remains subjective. For other purposes, it seems best not to attempt to draw a bright line between tax and spending provisions. The absence of a bright line will, among other things, allow constitutional litigation to focus on a tax provision's subsidy effect without argument over whether the provision is "truly" a tax or a spending program.

Identifying substitutable tax provisions will not solve all the problems with the tax laws. Tax simplification poses many technical and political hurdles, and removimg substitutable provisions from the tax code is a mere prerequisite for reforming the tax system's remaining provisions, a formidable task that the 1986 TRA only began. 